Portland State University

PDXScholar

5-5-1995

\title{
The Portland Public School Police: Formative Years - 1937 to 1953
}

Natalie Anne Woods

Portland State University

Follow this and additional works at: https://pdxscholar.library.pdx.edu/open_access_etds

Part of the Administrative Law Commons, and the Public Administration Commons Let us know how access to this document benefits you.

\section{Recommended Citation}

Woods, Natalie Anne, "The Portland Public School Police: Formative Years - 1937 to 1953" (1995).

Dissertations and Theses. Paper 5222.

https://doi.org/10.15760/etd.7098

This Thesis is brought to you for free and open access. It has been accepted for inclusion in Dissertations and Theses by an authorized administrator of PDXScholar. Please contact us if we can make this document more accessible: pdxscholar@pdx.edu. 


\section{THESIS APPROVAL}

The abstract and thesis of Natalie Anne Wood for the Master of Science in Administration of Justice were presented May 5, 1995, and accepted by the thesis committee and the department.

COMMITTEE APPROVALS:
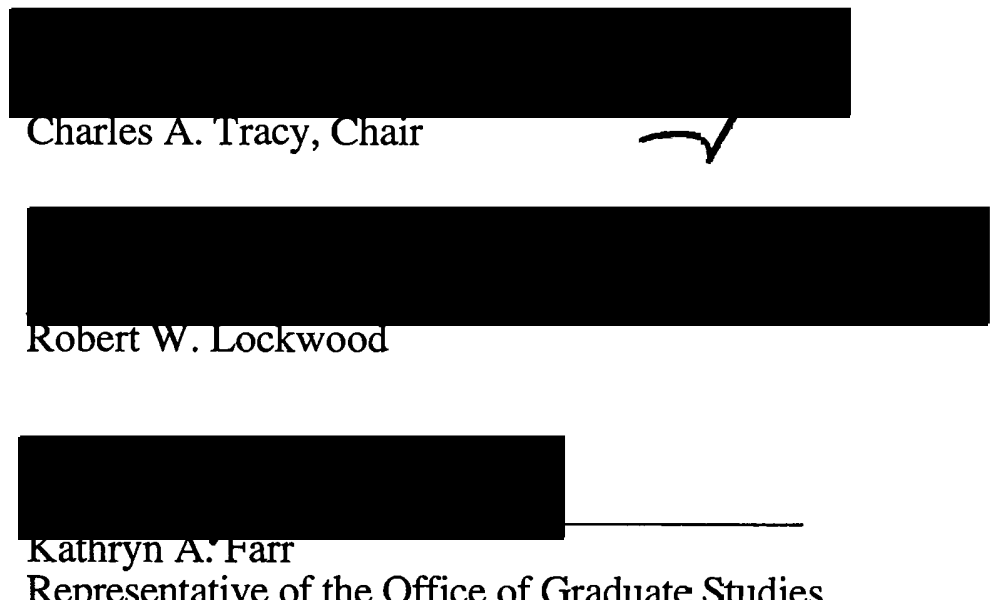

Representative of the Office of Graduate Studies

DEPARTMENT APPROVAL:

Robert W. Lockwood, Chair

Department of Administration of Justice

$* * * * * * * * * * * * * * * * * * * * * * * * * * * * * * * * * * * * * * * * * * * *$

ACCEPTED FOR PORTLAND STATE UNIVERSITY BY THE LIẸRARY

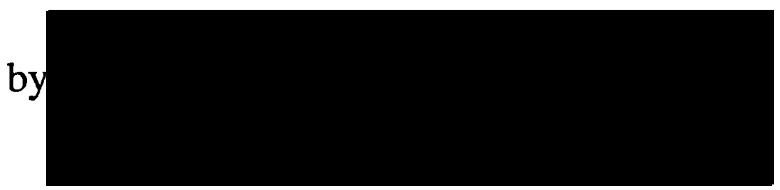

on

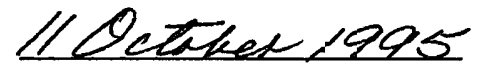




\begin{abstract}
An abstract of the thesis of Natalie Anne Wood for the Master of Science in Administration of Justice presented May 5, 1995, and accepted by the thesis committee and the department.
\end{abstract}

Title: The Portland Public School Police: Formative Years---1937 to 195?

This thesis traces the historical evolution of one of the early responses to youth crime and violence -- public school police. In addition, this thesis addresses the lack of information about the creation and implementation of a public school police force, specifically the Portland Public School Police and School District No. 1, during its formative years, 1937 to 1953 .

Finally, the thesis intends to address two principal questions: A) Why did the Portland Board of Education find it necessary to create their own police agency? While one opinion suggests that there was a real need for school police due to the escalating crime taking place within the school district, the other opinion suggests tha: the school police were created mostly for underlying political reasons rather than general public safety. B) What were the principal functions of the School Police? The iritial function of the Portland Public School Police was to protect school property and reduce the monetary loss incurred by the school district. However, after 1941, when iarge number 3 of immigrants came to Portland with their school-age children, the Portland Public School Police expanded their function from property protection and reduction of monetary loss to include crime repression and protection. 


\title{
THE PORTLAND PUBLIC SCHOOL POLICE:
}

FORMATIVE YEARS-1937 TO 1953

\author{
BY \\ NATALIE ANNE WOOD
}

A thesis submitted in partial fulfillment of the

requirements for the degree of

MASTER OF SCIENCE

in

ADMINISTRATION OF JUSTICE

Portland State University

1995 
TABLE OF CONTENTS.

CHAPTER 1: INTRODUCTION

$\begin{array}{ll}\text { Background } & 1\end{array}$

Problem Statement 5

$\begin{array}{lr}\text { Research Questions } & 6\end{array}$

$\begin{array}{lr}\text { Definition of Terms } & 6\end{array}$

$\begin{array}{ll}\text { School } & 6\end{array}$

$\begin{array}{ll}\text { Portland Board of Education } & 7\end{array}$

$\begin{array}{ll}\text { Portland School District No. } 1 & 7\end{array}$

$\begin{array}{ll}\text { School Police } & 7\end{array}$

$\begin{array}{ll}\text { Police Authority } & 8\end{array}$

$\begin{array}{lr}\text { Literature Review } & 8\end{array}$

$\begin{array}{lr}\text { School Police } & 9\end{array}$

$\begin{array}{ll}\text { School Crime and Violence } & 12\end{array}$

$\begin{array}{ll}\text { Research Design } & 14\end{array}$

CHAPTER 2: PORTLAND DURING THE 1940'S AND 1950'S 15

$\begin{array}{ll}\text { Introduction } & 15\end{array}$

Portland, A Strategic “Mecca”.

$\begin{array}{ll}\text { Demographics } & 16\end{array}$ 
The Social, Economic, and Political History

CHAPTER 3: EDUCATION AND DELINQUENCY IN PORTLAND 35 1943 TO 1953

Introduction $\quad 35$

Demographics In School District No. 1

Juvenile Delinquency $\quad 43$

Legal Definition $\quad 44$

Delinquency In Portland $\quad 46$

CHAPTER 4: PORTLAND PUBLIC SCHOOL POLICE

Formation $\quad 65$

Comparison of The Functions of The Portland Public School Police, $\quad 66$ 1937 to 1950 , and 1994 to 1995

CHAPTER 5: SUMMARY AND CONCLUSIONS 73

APPENDIX I: CHRONOLOGY OF IMPORTANT EVENTS IN 87 THE FORMATIVE YEARS OF THE PORTLAND PUBLIC SCHOOL POLICE 


\section{LIST OF TABLES:}

TABLE 1: Population For Oregon And MultnomahCounty By Total Non-White Ethnicity, And Under 19 Years Old For 1940 And 1950

TABLE 2: Population Of Oregon By Race For 1930, 1940, And 1950

TABLE 3: Population In Metro Portland, 1940, 1950, And 1960 To 1965

TABLE 4: Growth Of Vanport City Population, By Race

TABLE 5: Increases Of Violenct Crime In Portland, 1940 to 1946

TABLE 6: Comparison Of Certain Reported Crimes In Portland and Seattle. 1940 To 191946

TABLE 7: Numbers Of Students In Portland School District No. 1, 1943 To 1944

TABLE 8: Numbers Of Students In Portland School District No. 1, 40 1950 To 1951

TABLE 9: Percent Change In No. of Students Registered In Portland School District No. 1, 1940 To 1950

TABLE 10: Nativity Of Stuents Enrolled In Portland Public School District No. 1, 1943 To 1944

TABLE 11: Nativity Of Students Enrolled In Portland School District No. I 43 1950 To 1951 
TABLE 12: National Trends, Juvenile Court Statistics

TABLE 13: Local Trends, Juvenile Court Statistics

TABLE 14: Juvenile Delinquency Trends In Portland, 1937 To 1946

TABLE 15: Annual Report Of Portland School Police In 1948, 4 Year Survey 52

TABLE 16: Portland: Violence-related crimes reported at Portland Schools 53

TABLE 17: State:Violence-related crimes reported at state schools from 55 elementary to college.

\section{LIST OF FIGURES}

FIGURE 1: Kaiser Shipbuilding yards

FIGURE 2: Vanport City; Aerial View 


\section{CHAPTER 1.}

\section{Introduction}

\section{Background}

For years, society has been forced to withstand the egregious and quite often painful altercations of our youth, as conventional powers such as the police fiercely contend with the seemingly routine actions of society's adolescents.

Recently, articles and reports depicting adolescent violence in the U.S. have appeared daily in either our national or local newspapers, creating greater public awareness and concern over the future of our society and of our youth.

In addition, while the number of reports on adolescent crime have increased, so too has society's concern over our nation's schools and the destructive if not paralyzing effect violence has had not only on the students, but on the educat ors, the learning environment and the quality of education provided.

A recent study about school crime, conducted by the U.S. Department of Justice, (1991), provided the following demographics in reference to students:

* An estimated 21.6 million youths aged between 12 and 19 years were enrolled in the Nation's public and private schools between January and June of 1989. About $52 \%$ of these students were male and $48 \%$ were female. Approximately $30 \%$ were white; $16 \%$ African American; and 4\% from other ethnic backgrounds such as Asians, Pacific Islanders, Native Americans and Hispanics. 
* Approximately $13 \%$ of the students were in families that earned less than $\$ 10,000$ year and $16 \%$ were in families earning at least $\$ 50,000$.

* About $27 \%$ of the students lived in central cities, $47 \%$ in the suburbs, and $26 \%$ in non-metropolitan areas.

Additionally findings from the victimization survey focused on the crime experiences encountered by this population of school students and included:

* High school seniors were the least likely students to be crime victims, whereas, ninth grade students were more likely to be crime victims than were studerts in all higher grades.

* An estimated $9 \%$ of students, aged between 12 and 19 years, were crime victims in or around their school over a six month period, while $15 \%$ of the students said their school had gangs, and $16 \%$ claimed that a student had either attackeit or threatened a teacher at their school.

* Students of different races experienced about the same amount of violent or property victimization in and around their schools. However, Hispanic students were less likely than non-Hispanics to have sustained a property crime. (U.S. Department of Justice, September 1991, NCJ. 131645).

Closer to Portland, the November 15th, 1993, edition of The Oregonian, reported in an article entitled, "School Violence Erupts":

* Increasing conflicts among high-school students seem to be resulting in ccts of violence involving guns, knives, clubs and baseball bats. For example, a series of 
fights among a crowd of 150 to 200 students nearly sparked a riot at a GreshamBarlow football game.

* An 18 year old Gresham High School student required surgery after he was stabbed in the stomach on the night of the school's football game against Parkrose; the incident is believed to be gang related.

Furthermore, the October 16th, 1994, edition of The Oregonian, reported in an article entitled, "Making Schools Safe: violence-related crimes rise in schools":

* The number of violence-related crimes being committed on the campuses $\mathrm{cf}$ Portland Public Schools increased 11.2\% from 1992-1994 to 1993-1994.

* In addition, overall gang activity, child sexual abuse, criminal mischief felonies, robbery and the carrying of concealed weapons on school grounds have dropped; these crimes on the decline were offset by increases in assaults, arsons, burglaries, criminal mischief misdemeanors, physical child abuse and neglect, disorderly conduct and sex offenses.

Finally, the 1991 Statistical Abstracts produced by the U.S. Department oi Justice, reported that from 1982 to 1991 , there was an $18.6 \%$ increase in the number of people arrested overall, a $5.6 \%$ increase for those individuals under 18 years of age and $21.5 \%$ increase for individuals above the age of 18 years.

In addition, the December 31st, 1993, edition of The Oregonian entitled 'Data show youths commit growing share of killings", conclude the year by reporting: 
* Nationwide, from 1986 to 1991 , the homicide rate among 14 to 24 year olds rose by $62 \%$. It jumped $124 \%$ among those 14 to 17 years.

Consequently, with a slow but gradual increase in youth crime and violence, much of which is occurring in public and private schools, law enforcement agencies have begun to move away from the traditional reactive modes of policing to a newer proactive approach in an attempt to reintroduce community-based policing and interagency collaboration into their practices and amongst their constituencies.

Clearly, both street crime and violence appear to be escalating, both in thein intensity and frequency, amidst conflicting opinions regarding the rate of urbaz decay, the lack of social integration and dissipating family values, and cries for help from all economic classes.

However, before we can begin to consider changes in public safety, it is important to understand and appreciate past attempts to control crime and violence, particularly in our schools.

For much may be learned from the study of history, despite the all too common negative and unresponsive impressions afforded to many historical events by members of modern day society. History may be viewed as past precedent for future endeavors and may be indispensable to social reform, by illustrating previous examples and their relevance to current situations. 
William A Williams provided an excellent example of the important use of historical research, as a means to “...transform history as a way of learning into a way of breaking the chains of the past." (Williams, pp. 5-6, 1966).

This thesis traces the historical evolvement of one of the early community responses to youth crime and violence - a public school police.

\section{Problem Statement}

The problem that this thesis addresses is the lack of circumstances surrounding the creation and implementation of a public school police force, specifically the Portland Public School Police and School District No 1, during its formative years 1937 to 1953.

A significant point, is that while we, as society, know very little about School Police, it has become the latest phenomenon in controlling the rise in youth crime. For example, while little research exists on School Police, and it has yet to be evaluated, both law enforcement and educators across the nation seem to be practicing this method of crime control within the school districts. This alone seems justification enough to research School Police, in that the lack of information surrounding the latest if not most controversial subject amongst law-enforcement, educators and the community is slowly being implemented into our schools nation-wide to combat adolescent crime. 
Furthermore, after reviewing the literature and discussing the topic with various scholars in the field, I have concluded that there exist two competing arguments as to why an agency such as the school police was created at this particular time in kistory.

While one opinion suggests that there was a real need for school police, due to the escalating crime taking place within the school district, the other opinion suggests that the school police were created mostly for underlying political reasons rather than general public safety.

However, regardless of the reasons, it should be noted that Portland's experience with a public school police force is unique and, therefore, cannot be generalized to other school police departments in other cities.

\section{Research Questions}

The following two principal questions focused the analysis of the collected data:

A) Why did the Portland Board of Education find it necessary to create their own police agency?

B) What were the principal functions of the School Police?

\section{Definition of Terms}

$\underline{\text { School }}$

High Schools within Portland School District No 1 during 1937 and 195ミ. 


\section{Portland Board of Education}

The governing body over all school districts within Multnomah County, Oregon, during the period of study, (1937 to 1953), consisted of seven members, who were each elected to serve a term of four years, and who met bi-monthly to set policies and to adopt budgets for Portland Public Schools.

\section{Portland School District No. one}

A geographical district located within the Portland metropolitan area, which during the period of study, (1937 to 1953), was the largest school district in Multnomah County, with a total of 7 high schools, 67 regular/elementary schools, 5 special schools and 2 polytechnic schools.

\section{$\underline{\text { School Police }}$}

A law enforcement agency which has been charged by both the State Legislature and the local School Board, to provide a safe, healthy and secure learning environment within the boundaries of the school, by performing duties such as: crime prevention, enforcement, community service and career development for the general student population. 


\section{Police Authority}

Governmental control over the community through laws or regulations enacied for the welfare of the people by city, county, state, or federal political bodies.

\section{Literature Review}

School police is a relatively new phenomenon, with very little past documentation or existing published research about their history or current activities. However, despite this lack of available data, I have compiled periodicals and texts that focus on school police, and provide a great deal of insight on School Liaison Officers, as they are often referred to, and their role within schools.

However, it is important to note that while many of these articles are almost 30 years old, they not only provide a great deal of insight into the evolution of School Police, but as previously mentioned, they represent the scarcity of existing data $\{$ and the current void in research that this thesis intends to address.

Furthermore, while many of these articles discuss the issue of School Police during the 1960's and 1970's, the issues being discussed differ from that of the agencies [School Police] earlier concerns, in that the School District in the early 1940:s and 1950 's were primarily concerned with the monetary loss incurred through ac:s of adolescent crime, rather than the issues that face even today's agency such as civil liberties violations, methods of communication and specialized services. However, one common concern these articles share throughout the course of time by the 
agency, is the rise in youth crime and the overall effort by both law-enforcemen: and educators to reduce it.

School Police.

Articles by Sheppard and James (1967), Robinson (1967), discussed the controversial issue of placing law-enforcement officers within the schools.

Some advocates such as local school boards, educators, local businesses, parents and law-enforcement, support the program, while others such as the American Civil Liberties Union strongly opposes it.

The main argument of those in favor of the program, is that police presence in the schools decreases criminal activity; it creates a safe zone for all students; it encourages a channel of communication between educators, police and the students; it establishes community collaboration, respect for social values and problem solving.

However, its opponents question the ethical and legal ramifications, if not overall appropriateness, of having an outside agency interrogate and discriminate against students, in addition to the pure invasion of privacy.

The articles continue to address each pro and con of police in the schools, by analyzing various schools around the country that have implemented the School Police program.

Indeed, both sides present strong arguments, but despite the fact that School Police programs are relatively new and under-researched, many school districts have 
adopted and continue to adopt a School Police program in an effort to control the rise in youth crime and violence.

Wilson's (1984), article analyzes the goals of a successful School Police program, as implemented in the Wichita public schools, kindergarten through senior high.

The program's focus is on involving a significant proportion of the local citizenry in a collaborative effort to reduce crime. The goals are translated into specific earning experiences, jointly directed by police officers and class-room teachers, supervised by the program coordinator (Wilson, 1984, p. 284).

The Wichita program had two basic objectives: A) To develop a training program for teachers on law studies education and $\mathrm{B}$ ) to prepare a $\mathrm{K}$ through 12 curriculum in civics and legal education focusing on such topics as authority, justice, freedom, participation, diversity, privacy, property and responsibility.

Milander's (1969), article analyzed and evaluated the extent of local police department school system interaction and cooperation in 13 Illonois school d-stricts, along with establishing guidelines which both the local police department and school system could use in their relationships with each other (p. 26).

The article goes on to explain the areas of concern in communications between police, educators and students, but the overall importance that this article provides is the foresight into future problematic areas a School Police program can expect concerning patterns of communication. 
Furthermore, in their study, Surratt and Katzenmeyer (1975) consulted school superintendents in districts with over 10,000 students and police chiefs serving 418 of these 771 districts, about the growing use of police services in the schools.

Based upon statements of school and police officials, the researchers concluded that there was a high and continuously growing level of police involvement in the public schools, in the early 1970 's, in areas such as safety and control, school events, protection of building, patrol and instruction and counseling.

In addition, the authors pointed out that the present mandate of Congress fcr the Office of Education to study school security problems, (Education Amendments of 1974), testifies to a national concern for school crime. This study alone may ensure greater police involvement in the schools (p. 60).

Finally, Scheffers book, (1987), on policing from the schoolhouse, provided a vast amount of background information concerning the role/function of a school resource officer, particularly about the many controversial issues, such as the ones previously mentioned, surrounding the coalition between education and law enforcement.

Each periodical and text listed above provides insight into the realization and implementation of police in the school, their function and procedure, patterns of communication, advantages and disadvantages, and goals, and future expectctions. 
School Crime and Violence.

The U.S. Department of Justice's Statistics on School Crime: A national Crime Victimization Survey Report, The Office of Juvenile Justice and Delinquency Prevention's Juvenile Court Statistics, 1991, and periodic newspaper articles from The Oregonian and USA Today, have been seemingly endless in providing information on school crime and violence both on a national and state level.

Furthermore, books by Quarles (1989), School Violence: A survival Guide for

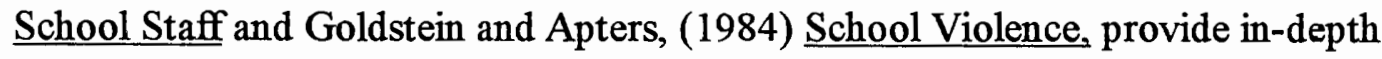
discussions on the scope of adolescent violence within the classroom.

Many, if not all of these sources tend to concur on one particular point: that school crime and violence is gradually increasing, but it is not so much the increase in adolescent crime that is alarming but the seriousness of the criminal acts.

Furthermore, much of the research identifies alternative security measure nany schools across the nation are being forced to implement, to decrease the number and intensity of criminal acts. For example, metal detectors, video surveillance cameras and drug detecting K-9's are becoming a common sight at many schools in an effort to create a safe haven from community and family-related problems. And, while educators agree that steps such as the ones just mentioned may seem extreme, they are prepared to justify their actions simply out of necessity. 
The research further suggests that it is not the schools themselves that provoke or encourage weapon-related violence, as much as they represent a convenient location or neutral territory for these acts to take place.

However, the school districts have not merely settled for a law-enforcement approach to the violence, as many schools have adopted anger-management classes that teach students to become mediators amongst their peers, in addition to teaching basic conflict management skills.

For example, programs such as 'The Conflict Wheel', where a frog named Kelso provides students with several problem solving solutions, through the use of a piegraph, have been implemented nationwide and are found in many schools in Multnomah County.

Finally, the research suggests that neither the law-enforcement approach or the conflict -management approach, can truly be effective in reducing school violence if the external conditions that promote it are not addressed.

In conclusion, it is important to note that while school crime and violence gradually increase, so too do our methods to combat it; and while our hopes to eradicate crime project our dreams of Utopia, we are forced to settle for the agents that merely decrease it. 


\section{Research Design.}

For the purpose of this study, a traditional historical research design was employed. Secondary data such as newspaper articles, official documents and records from public agencies were analyzed, in order to produce a chronological account of the formation and evolution of the Portland School Police, including the important political and social events that may have influenced its development.

For example, the minutes of the Portland Public School Board, the official records of the Portland Public School Police, the Portland Police Bureau and news items in The Oregonian were examined.

In addition, reports from the Portland Planning Bureau and U.S. Census Bureau provided important demographic information which focused upon student population and diversity, to adolescent crime and violence.

Finally, interviews of public officials with knowledge about the Portland Schaol Police were conducted to obtain contemporary perspectives of its historical growth and activities. 


\section{CHAPTER 2}

\section{Portland During the 1940's and 1950's}

\section{Introduction}

The lack of appreciation for the potential contribution of history permeates the infrastructure of the criminal justice discipline. History should play a larger role in criminal justice education, as it allows us to understand the values, experiences and social forces that shaped our culture and institutions. Without that knowledge to anchor our beliefs and provide perspective, we could not assess and respond to contemporary social change. In other words, we view current experience through the lens of our past. (Conley, 1993. pp. 349-352).

With the above philosophy in mind, a piece of Portland's past is here presented in order to understand its economy, social stratification and political movements that inspired the evolution and growth of social agencies such as the Portland Public School Police, during the 1940's and 1950's.

\section{Portland, A Strategic "Mecca"}

Prior to the 1950's, Portland was considered a "Mecca" for aspiring industries, because from a strategic standpoint no other state in the nation could compere with either its economic character or industrial specialization. For example, Portland's location between the Cascade Range and Columbia River, provided an abundance of 
natural falling water and thus electrical power, accompanied by the rich and fertile land of the Willamette, Cowlitz and Tualatin valleys. All of this provided Portland with both prosperous manufacturing and non-manufacturing industries; easy aczess to eastern markets and with sufficient remoteness and long distances between other industrial centers on the west coast. (Portland City Planning Commission, 1957 $\mathrm{i}$ pp. 28-73).

\section{Demographics}

Clearly, Portland had become an industrial gem in the eyes of the nation, attracting people from not only within the boundaries of the United States, but from various other geographical areas around the globe. For example, Table 1 shows that the State of Oregon experienced almost a $40 \%$ increase in total population, while Multnomah County, in which the city of Portland is located, received an overall increase of $33 \%$ from 1940 to 1950 . However, while the growth of the city was seen as a success by many of Portland's' 'industrial giants", Portland city planners were grossly underprepared for such an influx of immigrants, as attempts to develop more housing, expand the city's social services and re-think the transportation system were becoming a constant headache. 
Táble 1

Population For Oregon and Multnomah County, By Total Non-White Ethnicity: And Under 19 Years Old for 1940 And 1950.

TOTAL

YEAR

1940

1950
NON-WHITE

STATE MULT

$1,089,684 \quad 355,099$

$1,521,341 \quad 471,537$
STAT

13,953

24,213
AGE 0-19 YEARS

STATE MULT

323,663

86,787

$15,378 \quad 500,389$

132,722

Source: U.S. Census 1950, Part 37, Vol. II.

Furthermore, while native Oregonians were being exposed to a population 'boom"' and major industrial overhauls in the large cities, Oregonians were also being exposed to "diversity", in that the non-white population in the State of Pregon had increased by $74 \%$ over the course of a decade. In particular, as shown in Table 2 , the black population alone had grown by a staggering $349 \%$ from $1940(2,565)$ to $1950(11,529)$ (Little, 1978. pp. 58-59); Oregonians would protest this "invasion" throughout the century as will be discussed in a later section of this thesis. 
Table 2

Population of Oregon by Race for 1930, 1940, and 1950.

$\begin{array}{cccc}\text { YEAR } & 1930 & 1940 & 1950 \\ \text { NEGROES } & 2,144 & 2,565 & 11,529 \\ \text { ALL RACES } & 953,786 & 1,089,684 & \text { NOT AVAILABLE }\end{array}$

Source: U.S. Bureau of Census, and Little, 1978. p. 58.

It should be noted that the population growth did not just involve adults, as these newly arriving immigrants brought their families with them. For example, Tabde 1 indicates that Oregon received a 55\% increase in adolescents under the age $0=19$ years from 1940 to 1950 ; only $2 \%$ more than that of Multnomah County. This again caused a few problems for the City of Portland officials, in that they were faced with increasing demands from school administrators and social services for bigger facilities and more funding.

From 1940 to 1946, Portland's population grew by $35 \%$ - a figure that would decline and stabilize at $20 \%$ by 1950 . (Table 3 ).

World War II was largely responsible for the increase, much of which was accounted for by the 94,000 workers employed by the three wartime Kaiser shipyards (McColl, 1979, p. 555). 
Table 3

Population in Metro Portland, 1940, 1950, and 1960-65.

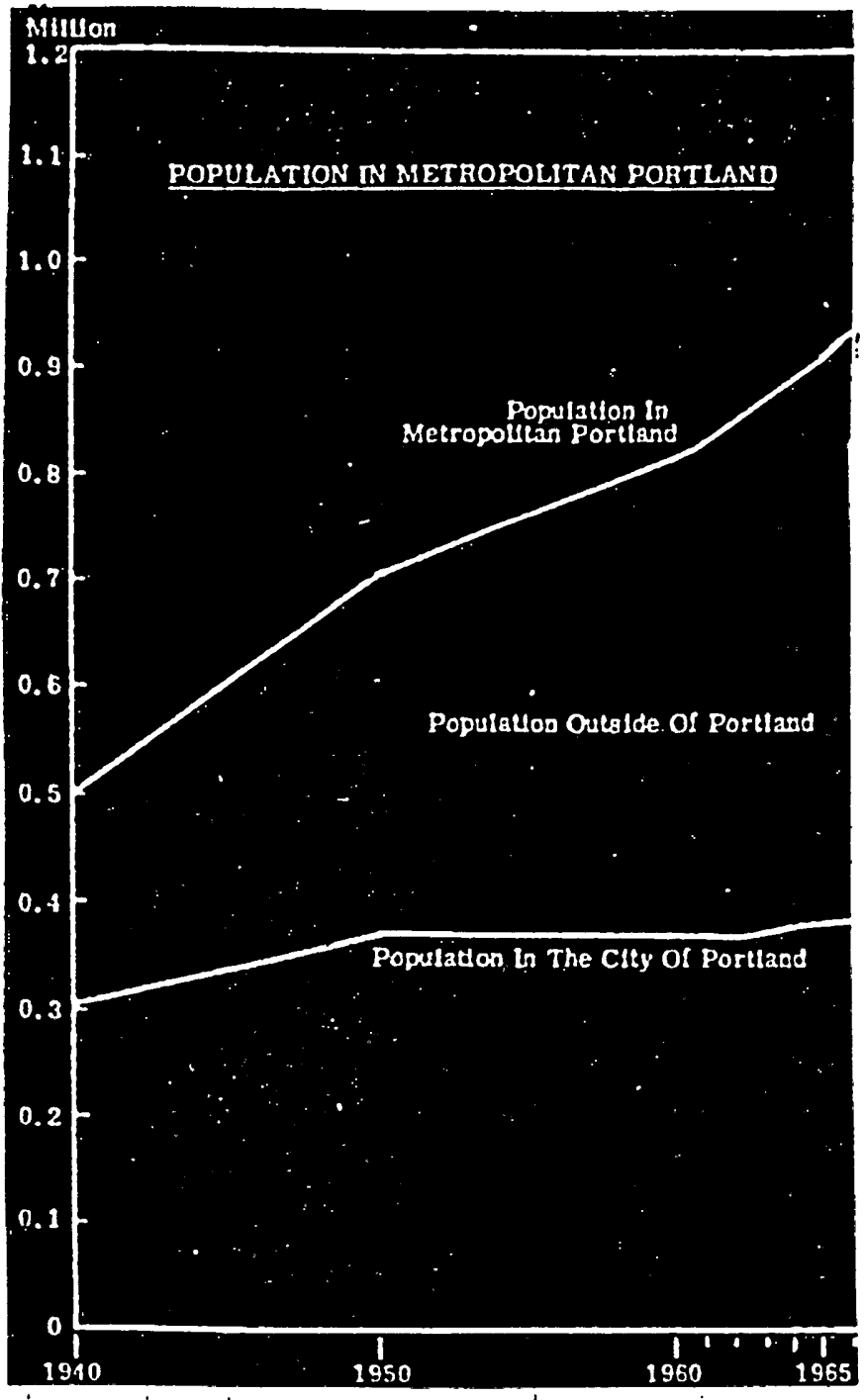

Source: MacColl, (1979). p. 556 


\section{The Social, Economic, and Political History.}

Inspired by the bombing of Pearl Harbor, December 7th, 1941, when the United States entered World War II, the ship building industry along with many war-time businesses in Portland began to boom, and thousands of immigrants created a population growth in Portland of 160,000 in only two years (Meehan, 1992. p. A12). This increase of immigrants caused civil unrest and discrimination towards not only the Japanese but towards every person of color. Gordan Demarco seemed to sum up many Oregonian's sentiments when he mentioned: “...Oregon has always been seen by outsiders as a state full of white people. White American people. However, although both Oregon and Portland were bastions of settlerist nativism and racism, it was not the post-Confederacy south of racial lynchings. The prejudice towards Blacks and Asians was, for the most part, physically non-violent," (Demarco, 1990. pp. 47).

However, while many Oregonians had opposed physical violence, Executive Order 9066 enacted on February 19th, 1942, by the Federal government, confirmed the nation's racial hatred and bigotry, as approximately 110,000 Japanese-Americans on the west coast were ordered to sell all their property within 5 days and report for processing to an internment camp where they remained until 1945. There are many compelling arguments that support the idea that this was really a well-plannea operation to take the land away from the Japanese in order to prevent further competition to the American growers. Many farmers, including the Washington 
County Growers Association in 1945, petitioned the permanent deportation of Japanese-Americans.

After the war, many Japanese-Americans managed to return to their homes, but it took many years before their families were completely reunited, if at all. While the government attempted to make minor monetary compensation, this neglected to heal the deep mistrust many Japanese-Americans still have for our government today (Demarco, 1990. pp. 131-132).

The bombing of Pearl Harbor in 1941, did more than create an atmosphere of racial hysteria; it also inspired the government to launch several billion dollar contrazts to industrialists across the country, one of whom was Henry Kaiser. Kaiser came in Portland in 1941, after buying out the Todd Shipbuilding Company, and produced approximately 1,000 Liberty ships throughout the duration of the war. He established the largest shipbuilding company in the nation, and became the nation's leading employer as approximately 72,000 migrant workers swarmed into the city by every known means of transportation (Figure 1 shows the location of his three yarcs). Kaiser actively recruited workers in the East and South and ran special transcontinental trains directly to Portland. Overnight, Portland became a high pressure defense city. (MacColl, 1979, p. 575).

In its peak, Kaiser's shipyards employed somewhere close to 115,000 workers and while the shipyards offered a wonderful opportunity to immigrant laborers, the City of 
Portland planners were faced with the overwhelming task of housing them - an enormous challenge even if they had prepared in advance.

Kaiser's son, Edgar, signed with the Maritime Commission in August of 1942 to build a housing complex that resulted in 10,000 new accommodations on the floodplain of the Columbia River. By September of 1943, Kaiser's prodigy 'Vanport" had been built, despite the reluctance of the Portland Housing Authority - a privately built agency comprised of real estate agents, bankers, and mortgage investors that had successfully monopolized Portland's housing projects, and isolated Portland's elite from not only the working class but from all people of color.

Figure 1.

\section{Kaiser Shipbuilding Yards}

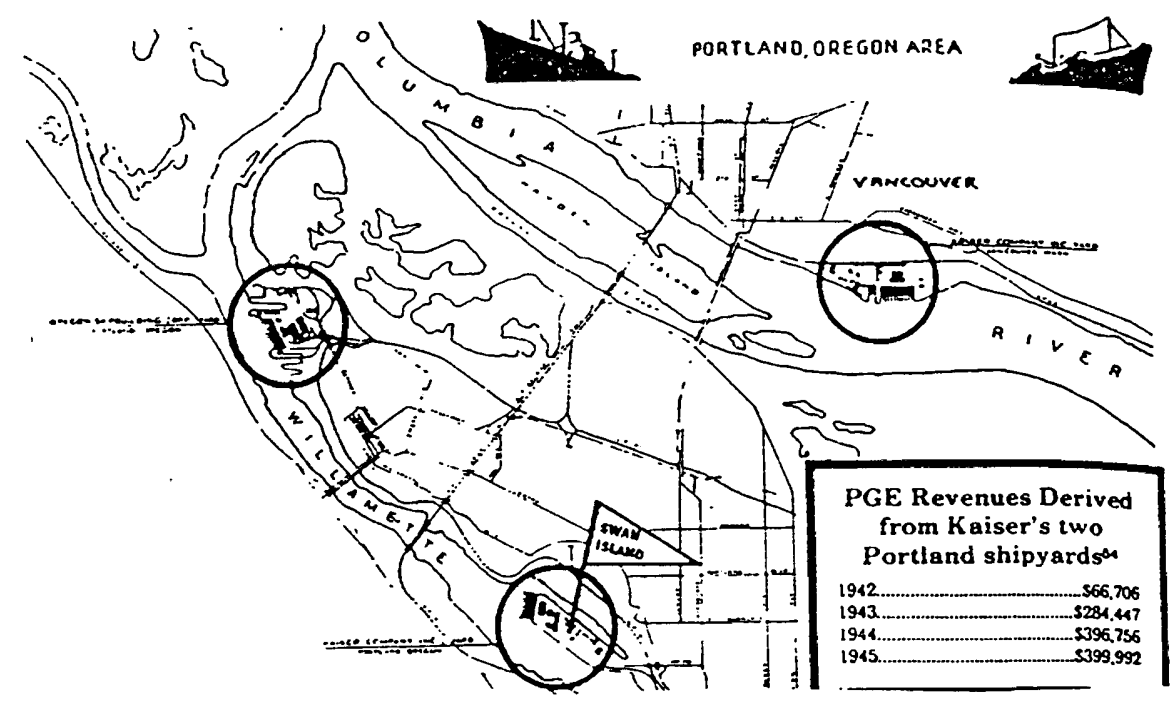

Source: MacColl, (1979). p. 576. 
When the Vanport housing project was finally completed in September of 1943, its reputation quickly grew, making it one of the world's largest housing communities ever to be constructed. It had its own post office, five grade schools, four nursery schools, a fire station, a four hundred seat cafeteria, a 785-seat theater, a library, a hospital, a police station staffed by twenty two policemen, fourteen playgrouncis, sports areas, and five commercial centres, all of which were overseen by a city manager and a staff of six hundred (Demarco, 1990. p. 134) (See Figure 2).

However, it wasn't long before Vanport was considered one the world's worst examples of city planning. Built on an inadequately filled swamp between two major rivers, Vanport was never more than a huge collection of crackerbox houses strung together fast and cheap (McCusker, 1973 and McColl, 1979. p. 578).

While Vanport seemed to temporarily solve Portland's housing problems, it provided yet another unexpected crease in the plans. The Housing Authority of Portland had not envisioned accommodating such an enormous influx of black immigrant workers, who faced open discrimination on a daily basis.

For example, in the February 26th, 1995, edition of The Oregonian, in an article entitled "The Ship Builders", several personal life stories of African American ship yard workers were documented.

The article focused on the open bigotry, segregation and unemployment that many, if not all, African Americans experienced throughout the war and post war years in Portland. 
Augustine Roland worked as a machinist helper at a Vancouver shipyard owned by the Kaisers, and he vividly recalls daily encounters with blatant discrimination. Roland discusses instances such as the time he along with many other African Americans were laid off after the war and the only available work went to whites, as unions shut their doors to black workers, whether they were skilled enough to do the job or not; a position supported by many of the city's restaurant owners, who openly displayed signs in their windows that stated "White Trade Only". This understanding extended into the schools and theatres, so much so, that many African Americans described Portland's similarity to the South and its beliefs.

By the middle of 1945 , Vanport alone had a black population of $6,317,20.4 \%$ of the town's population (see Table 4). For a town still clutching to "Jim Crowism" it was indeed a time bomb waiting to explode. 


\section{FIGURE 2}

\section{VANPORT CITY}

Aerial Map of the World's Largest War Housing Community

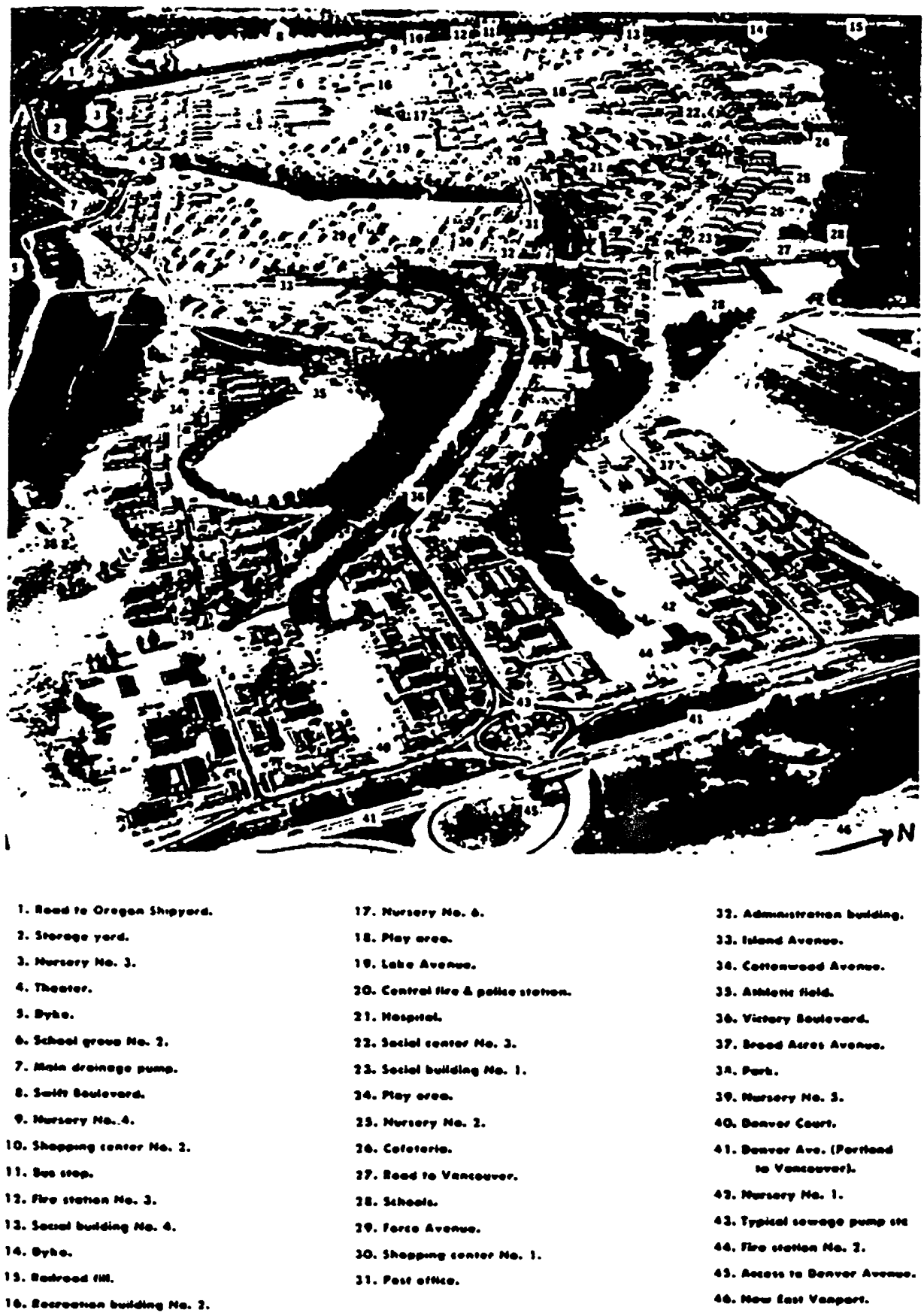

Source: MacColl, (1979), p. 579. 
Table 4

GROWTH OF VANPORT CITY POPULATION, BY RACE

$\begin{array}{ccccc}\text { DATE } & \text { WHITE } & \text { BLACK } & \text { TOTAL } & \text { \% BLACK } \\ \text { JAN 30, 1943 } & 4,840 & 1,176 & 6,016 & 19.5 \\ \text { JUN 30, 1943 } & 22,932 & 2,156 & 25,088 & 8.5 \\ \text { JAN 30, 1944 } & 28,160 & 2,159 & 31,093 & 6.9 \\ \text { JUN 30, 1943 } & 23,232 & 3,818 & 27,082 & 14 \\ \text { NOV 1, 1944 } & 26,656 & 5,808 & 32,622 & 17.8 \\ \text { MAY 1, 1945 } & 24,525 & 6,317 & 30,842 & 20.4\end{array}$

Source: Bureau of Planning, 1993. p. 74.

The strong racial hostility prevalent amongst Oregonians and the Housing Authority of Portland, was clearly stated in 1939 by a prominent Portland realtor, Chester A. Moores:

'We were discussing at the Realtor Board recently the advisability of setting up certain districts for Negroes and Orientals. We talked about the possibility of creating desirable districts which would actually cater to those groups and make life more pleasant for them. After all, they have to live too, the same as youngsters" (quoted in Portland, 1939. p. 144., and MacColl, 1979. p. 540).

"If it is necessary to bring in large numbers of Negro workers, locate them on the edge of the city", urged the President for the Central East Portland Community Club. 'It would be much better for all concerned. If they are allowed to fan out through the 
city it soon will be necessary to station a policeman on every corner" (quoted ir Wesley, 1984., and Portland Bureau of Planning, February 1993, p. 64).

These public statements are evidence that segregation and racial hostility were alive and well in Portland during the 1940's. It did not just extend to those in public housing, as open racism was felt on the streets, in local restaurants in retail stores, and more prominently in the workplace.

For example, the unions in the shipyards had openly protested membership by any non-white immigrant and when the California State Supreme Court ruled segregation in the workplace illegal in 1944, it sent a strong and persuasive message to unions across the country including Portland. However, it still took a number of years before the union opened its doors and accepted the membership of non-white workers (Demarco, 1990. p. 135).

By 1943, the people of Portland were tired of the racial compromise/ social accommodation they had created for the good of the war, and with the war d-awing to a close, the city planners found themselves yet again faced with a socio-economic nightmare - what to do with all the immigrant workers!

After months of waiting for Portland's newly developed Postwar Development Committee (PAPDC) to create new development plans, the Kaisers yet agair saved the "decade" by bringing Robert Moses, New York City's Park Commissioner and the nation's leading public works designer, to Portland. 
Moses Improvement plan was published on November 10th, 1943, and centered around transportation rather than accommodation. It called for $\$ 60$ million to bz spent buying land, widening the roads and highways, creating an eleven block train station, bus depot, a twenty block civic center, improving the airport, docks and constructing of sewage disposal system for the Willamette. (Demarco, 1990. p. 137). Furthermore, the most important ingredient of his plan and the most desirable to Portland City's planners, was the destruction of the wartime housing projects, such as Vanport.

However, when the results of Kaiser's survey went public in 1944, (a survey of workers who wanted to remain in the Portland area after the war), it threw city planners into an emotional cardiac arrest, as nearly $52 \%$ of Kaiser's 91,000 workers wanted to remain in the Portland area after the war. Of the 3,461 Negroes interviewed, $14.4 \%$ definitely intended to stay, while $33.3 \%$ would stay if jobs were available (MacColl, 1979. p.583). Indeed, a significant last point, as the Moses' plan would create employment for at least 20,000 workers.

On May 30th, 1948, the Columbia River sent a 12 foot wall of water crashing through a six hundred foot section of the 33-foot high ring-dike that had protected the city of Vanport since its construction five years previously (See Figure 3). Miraculously, almost all of the community managed to evacuate safely with $a$ loss of roughly 14 to 18 people, notwithstanding prior assurances from the Housing Authority that although the residents' concerns were inappropriate at that time, they 
would receive adequate due notice for evacuation when the time was right. However, it should be noted that the death toll was debatable, as the following statement was taken from Rosa Lee a former resident: "They claimed that only a few people died. I didn't believe that. Because so many people worked graveyard and swing shift: Some people couldn't even get out. They pretend it was only thirteen people. But I never believed that. (Bureau of Planning, February 1993, p.80). Furthermore, Demarco, (1990, p. 139), makes an interesting notation when he mentions that Julia Ruuittila, a long-time labor journalist who covered the flood, maintained that the Housing Authority found time to evacuate its records and from Vanport and supermarkets had time to remove their safes, before the flood hit. (Demarco, 1990. p. 139).

Both the Housing Authority and the majority of Portlanders felt the flood was a blessing in disguise, as over 18,000 residents, $25 \%$ of whom were black, were left homeless. It was expected that they would return to their original homes now that Vanport was leveled (Refer to Figure 3, Map of Vanport). However, to their dismay, a vast majority of immigrant workers were now forced to remain in Portland due to the financial burden the flood had inflicted upon them; and consequently the City of Portland was now forced to absorb the unemployed flood victims.

By 1948 , crime and corruption both on the streets and within the police department had reached disgraceful levels, as local gambling, prostitution and embezzlement became rife. 
For example, Tables 5 and 6 , clearly indicate it becomes clear that crime rates in Portland had risen steadily over the past ten years. August Vollmer, a national police expert and retired Chief of Police of Berkeley, California, attributed this rise primarily to the lack of public concern and police responsibility.

Consequently, both the Portland City Club and August Vollmer made stinging remarks about the city of Portland. For example, the City Club report revealed how the existence of illegal activities, condoned by the police and higher authorities, corrupted the whole law-enforcement process. Vollmer supported these findings. He mentioned that for at least the previous seven years Portland's Police Bureau had been over costly, under-productive, poorly organized, inadequately supervised and underpaid. It was little wonder that Portland's crime rates had risen steadily for ten years (MacColl, 1979. pp. 609-613) (See Tables 5 and 6).

When Vollmer's report was published in The Oregonian on January 15th, 1948, it publicly embarrassed Mayor Earl Riley and his distinguished followers, many of whom were leading men in Portland's business community such as bankers, real estate investors, contractors and members of the City Council. 
Figure 3

Map of Vanport

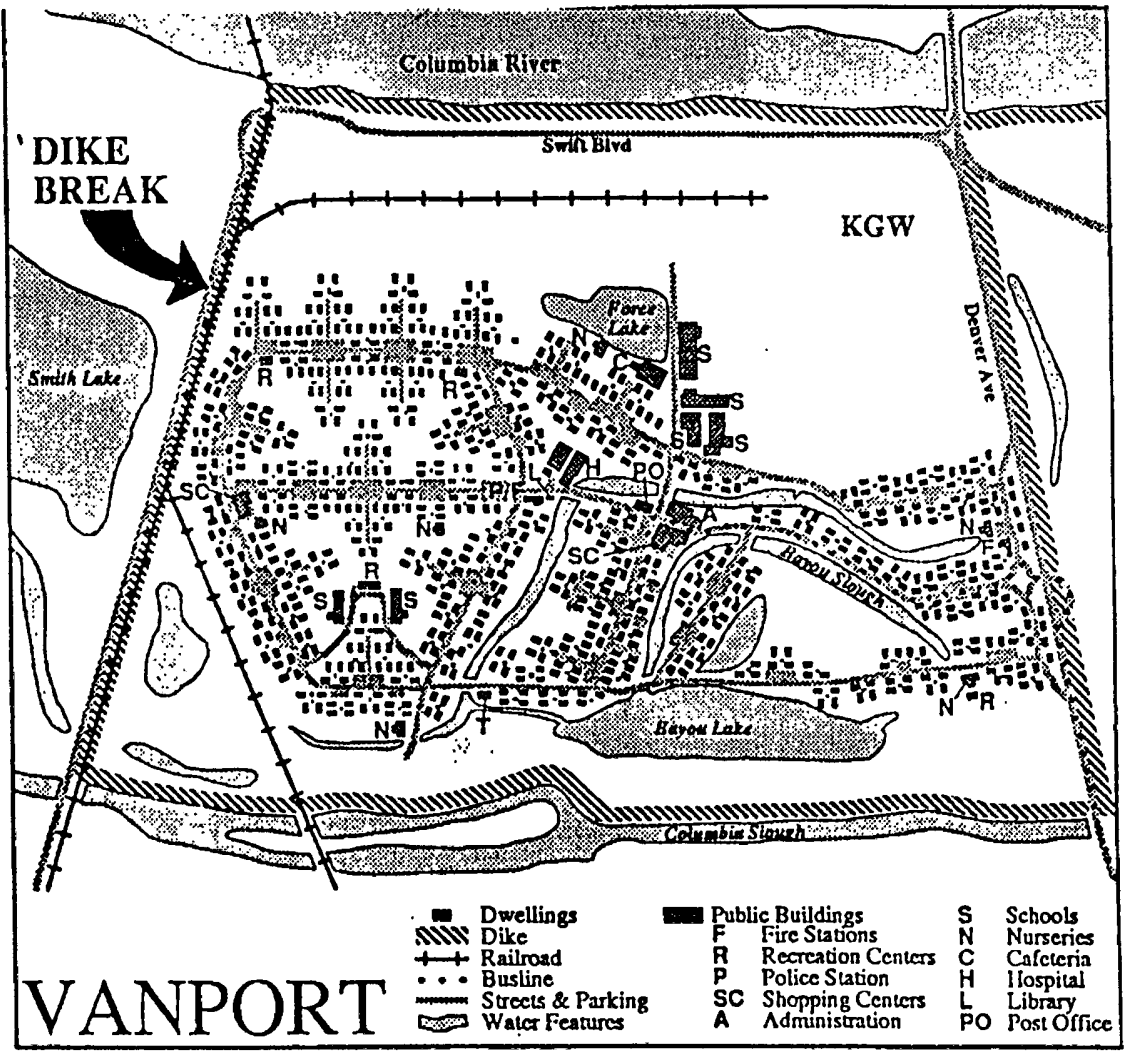

(Bureau of Planning map based on information provided by OHS) (1993), p.66 
As a result of the above findings, Portland's finance Commissioner Dorothy McCullough Lee publicly challenged Mayor Earl Riley (1941-1949), in an attempt to expose the corruption and become Portland's new mayor. She was successful in her campaign and while in office she fulfilled her promises to clean up Portland, and did so in such a vigorous and challenging manner that she earned a reputation as Dorothy McCullough 'No Sin'Lee.

\section{Table 5}

Increases of Violent Crime in Portland, 1943 - 1946.

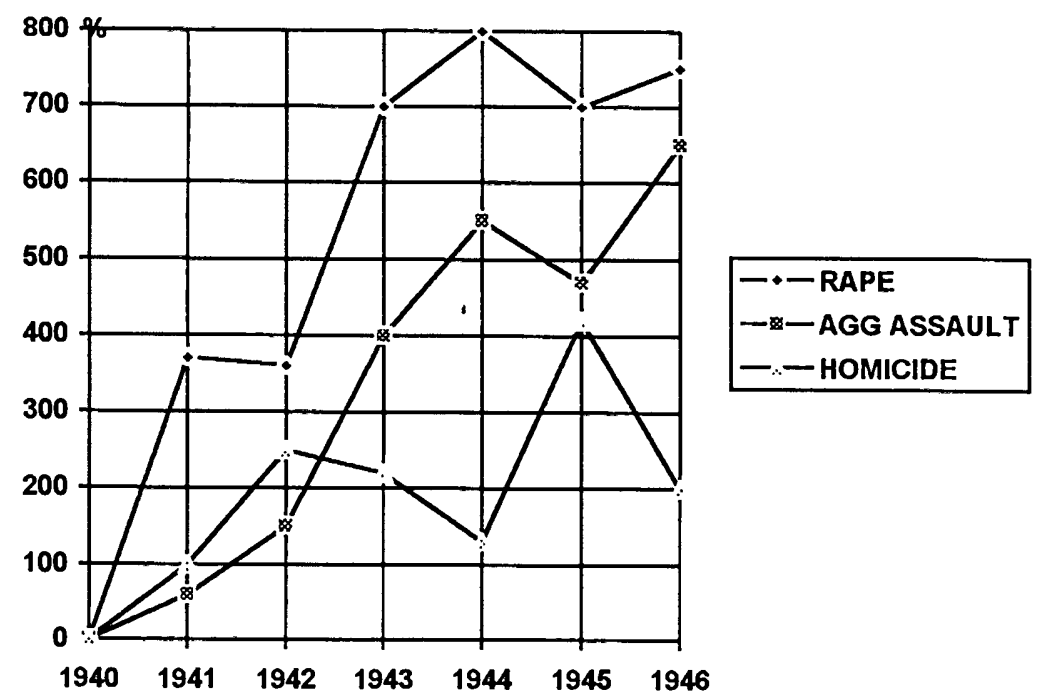

How rape, aggravated assault and homicide had increased in Portland since 1940 is shown in this sketch from the Vollmer report. Figures indicate percentage of increase over 1940. Auto theft also had mounted rapidly but burglary, larceny, robbery had increased by lesser percentages, Vollmer said. 
Homicides had increased in Portland 250 per cent since 1940, slightly above that of the same type of crime in Seattle. Portland robberies had increased only 60 per cent compared to Seattle's 178 per cent, however, according to Vollmer survey. See Table 6 below.

Table 6

Comparison of Certain Reported Crimes in Portland and Seattle. 1940 - 1946.

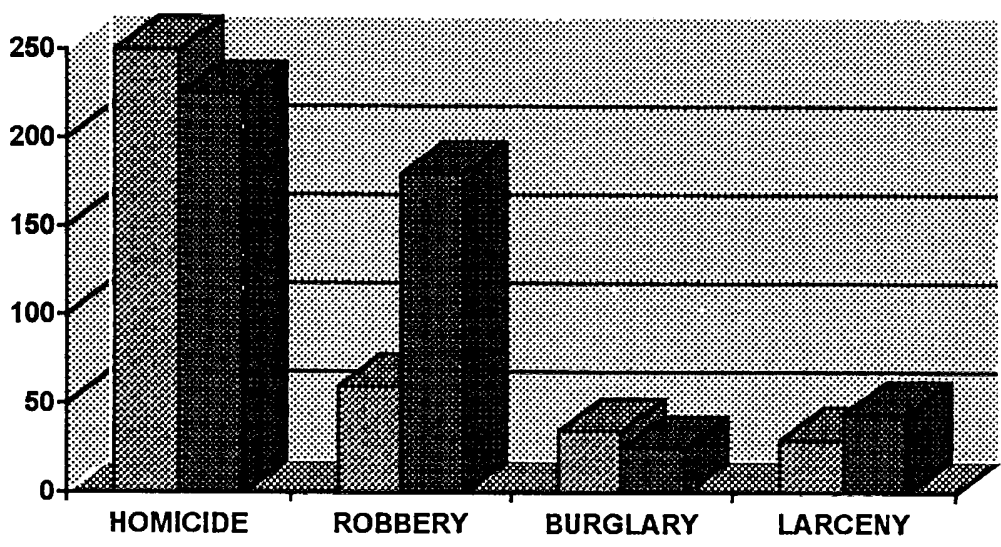

August Vollmer made this comparison in an attempt to illustrate the rise in crime between two cities that showed similarities not only geographically, but econ.omically, politically and socially

After witnessing an industrial revolution and population explosion, the earty 50's in Portland and in the State of Oregon were regressive at best, in that Portlanders were 
still absorbing victims of the Vanport flood, and reluctantly dealing with the city's multi-ethnic community, even though they had envisioned mass migration by its immigrant occupants once Vanport had dissolved.

The Kaisers had made their fortune in the shipyards and after their closure they left Oregon. Portland seemed to entered a postwar slump and unemployment era along with the rest of the nation.

The next chapter focuses on the public school system in Portland, both during and after the war years, and discusses in more detail how population growth, ethn:c diversity and influx of school crime and adolescent violence affected the education and lives of Portland's youth. 


\section{CHAPTER 3}

\section{EDUCATION AND DELINQUENCY IN PORTLAND: 1943 - 1953.}

\section{Introduction}

The 1940's and 50's were important years for Portland, as the City's industrial, economic, and political giants, such as Henry and Edgar Kaiser, Robert Moses. Mayors Earl Riley and Dorothy "No Sin Lee", helped raise the Rose City from the once "Sleeping Hamlet", to one of the leading metropolitan cities on the west coast.

After the 1948 Vanport flood, racial segregation and open hostility in Portlend momentarily seemed to relax, as the majority of Portlanders envisioned mass cutward migration by many of the city's people of color. However, to their dismay, the majority of Vanport survivors remained in Portland and were slowly absorbed by a vast amount of community support agencies, particularly those located in and around North East Portland and the Albina district - a low income, racially isolated neighborhood, populated primarily by people of color. Once again frustration and resentment arose, as the city's Housing Authority continued to segregate individuals not only in residential settings but in employment and educational settings also.

For example, the school system was still attempting to facilitate and manage the explosion in enrollment brought upon them during the war years. The increased burden of additional students placed those already enrolled in both a vulnerable and detrimental surrounding, and would eventually undermine the learning environment itself. 
Furthermore, as already mentioned in the previous chapter, adult crime and violence during the 1940's and 1950's had grown to unacceptable levels within the state of Oregon, as all major crimes, both person and property, showed a continuous and marked increase over the past decade (Tables 5 and 6). However, perhaps even more worrisome was the example it set for adolescents in the community, as juvenile delinquency increased $115 \%$ in a five year period, and during $1946,39 \%$ of the persons charged for part I offenses were juveniles (Vollmer, 1947. p. VIII)., either attending or capable of enrolling at local schools. Clearly, the problem of juvenile delinquency had become a real issue, and combined with racial hostility and community-wide segregation, it created a caustic and volatile environment for both law-enforcement and educators to resolve, both inside and outside the classroom.

\section{Demographics in School District No 1.}

Tables 7 and 8 show that, Portland School District No 1 maintained seven standard high schools from 1943 to 1950 ; with a total of 12,317 students registered in 194344 , or $22 \%$ of the total number registered throughout all schools $(56,538)$. During 1950-51 School District No 1 reported a total of 11,825 registered or $21 \%$ of the 56,187 students enrolled throughout the school term.

The average daily attendance for students ranged between $89-93 \%$ on any given day during 1943 , and $90-93 \%$ on any given day during $1950-51$ - A slight increase of about $1 \%$ in 7 years. 
However, Table 8, shows that the total number of registered high school stidents experienced only a 1\% increase between 1943 and 1950, while general enrollment in all levels of school climbed from 48,660 in 1940 to 56,187 in 1950, for an overall increase of $15 \%$.

In addition, Table 8 illustrates a significant increase in enrollment between 941 and 1945. In just 4 years, the total number of students registered went from 43,045 in 1941 to 58,373 in 1945 .

This increase of approximately $21 \%$ falls into a very important time period: and can be attributed to many different events, one of the more prominent being World War II, from 1939 to 1945. However, for Americans, the years 1941-45 were considered the primary war years, as the United States entered the war and the effects of the great depression were slowly dissipating as many small towns across the nation became industrial giants "overnight". Portland was one such city and, as previously discussed, the population growth exploded as immigrant families cane to wo-k in the Kaiser shipyards, and many of the local schools fought to absorb their children into local schools.

Another important event, the Vanport Flood, destroyed a rapidly decaying community and forced many, if not all, young students to be farmed out to neighboring schools. In addition, by reviewing Tables 10 and 11 , we can se that the total immigrant population, both white and non-white individuals, whose origin was not only outside the state of Oregon, but outside of the United States, comprised $40 \%$ 
of the school districts population in 1943 , and $43 \%$ in 1950 . With the immigrant population in the school district comprising almost half of the general enrollment, it might be speculated that native Oregonians viewed their schools as being overcrowded and ill-equipped to handle such an influx of someone else's students.

However, this fact does not support the communities fears, or justify any of the social and racial segregation that both the City and the schools practiced.

Finally, it should be noted that in 1937, the schools district hired the first school investigator, Edward Wolfe, who for a monthly salary of $\$ 125$ was appointed special investigator for School District No 1 on June 28th, 1937. Wolfe's primary duty was to reduce the amount of damage incurred and materials stolen from the schoo:

district. And, after reviewing the research, it can be noted that Wolfe's appointment as special investigator can be seen as the first recorded act that led to the formation of the school police (P.P.S.B.M, 1937. 11426-11643). 
Table 7

Numbers of Students in Portland School District No 1, 1943 - 1944

SCHOOL

COMMMERCE HIGH

FRANKLIN HIGH

GRANT HIGH

JEFFERSON HIGH

LINCOLN HIGH

ROOSEVELT

WASHINGTON HIGH
REGISTERED

1,291

1,637

2,168

2,600

1,547

1,437

1,637
$\%$ OF ATTENDANCE

91.0

89.9

93.1

90.4

89.7

89. D

91.7

Source: Portland Public Schools, (1943-44). Annual Report, pp. 72-80. 
Table 8

Number of Students in Portland School District No 1,

\begin{tabular}{ccc} 
SCHOOL & $1950-1951$ & \\
CLEVELAND HIGH & REGISTERED & $\%$ OF ATTENDANCE \\
FRANKLIN HIGH & 1,104 & 92.0 \\
GRANT HIGH & 1,961 & 90.1 \\
JEFFERSON HIGH & 1,992 & 92.8 \\
LINCOLN HIGH & 2,204 & $91 . \varepsilon$ \\
ROOSEVELT HIGH & 1,543 & $91 .:$ \\
WASHINGTON HIGH & 1,460 & 90.6 \\
\hline
\end{tabular}

* It should be noted that the years 1943 to 1944 and 1950 to 1951, in Tables 7 and 8,10 and 11, were used as they appeared to contain a more complete set of statistical data than other annual school reports from previous years that were fragmented, inconsistent and simply unavailable.

Source: Portland Public Schools, (1950-51). Annual Report, pp. 74-80. 
Table 9

Percent Change in Number of Students Registered in Portland School District No.. 1,

$\begin{array}{crc} & 1948-1950 & \\ \text { YEAR ENDING JUNE } & \text { REGISTERED } & \text { \% GAIN } \\ 1940 & 48,660 & - \\ 1941 & 48,045 & - \\ 1942 & 49,379 & 2.8 \\ 1943 & 54,655 & 10.7 \\ 1944 & 56,538 & 3.4 \\ 1945 & 58,373 & 3.2 \\ 1946 & 56,733 & - \\ 1947 & 49,814 & - \\ 1948 & 53,555 & 7.5 \\ 1949 & 55,651 & 3.9 \\ 1950 & 56,187 & 1.0\end{array}$

Source: Portland Public Schools, (1950-51). Annual Report, p. 80. 
Table 10

Nativity of Students Enrolled in Portland Public School District No 1, $1943-1944$

$\begin{array}{cccc}\text { SCHOOL } & \text { NON-IMMIGRANT } & \text { IMMIGRANTS * } & \text { TOTAL } \\ \text { COMMERCE HIGH } & 992 & 313 & 1305 \\ \text { FRANKLIN HIGH } & 1132 & 505 & 1637 \\ \text { GRANT HIGH } & 1434 & 734 & 2168 \\ \text { JEFFERSON HIGH } & 1304 & 1296 & 2600 \\ \text { LINCOLN HIGH } & 849 & 698 & 1547 \\ \text { ROOSEVELT HIGH } & 616 & 821 & 1437 \\ \text { WASHINGTON } & 1075 & 562 & 1637 \\ \text { HIGH } & & & 12,331\end{array}$

*Both white and non-white individuals, whose place of origin was not only cutside the state of Oregon, but outside of the United States.

Source: Portland Public Schools, (1943-44). Annual Report, pp. 72-73. 
Table 11

Nativity of Students Enrolled in Portland Public School District No 1, $1950-1951$

$\begin{array}{cccc}\text { SCHOOL } & \text { NON-IMIMIGRANTS } & \text { IMMIGRANTS } & \text { TOTALS } \\ \text { CLEVELAND HIGH } & 688 & 416 & 1104 \\ \text { FRANKLIN HIGH } & 1240 & 721 & 1961 \\ \text { GRANT HIGH } & 1223 & 769 & 1992 \\ \text { JEFFERSON HIGH } & 1217 & 987 & 2204 \\ \text { LINCOLN HIGH } & 845 & 698 & 1543 \\ \text { ROOSEVELT HIGH } & 643 & 817 & 1460 \\ \text { WASHINGTON } & 920 & 641 & 1561 \\ \text { HIGH } & & & 11,825 \\ \text { TOTALS } & 6776 & 5049 & \end{array}$

Source: Portland Public Schools, (1950-51). Annual Report, pp. 74-75.

\section{$\underline{\text { Juvenile Delinquency }}$}

There exist many different constructs within the literature, both past and present, that define "delinquency" and what it represents. However, for the purpose 0 - this study I have chosen an historical definition presented by the City Club of Porlland, in a 1948 Bulletin entitled "Juvenile Delinquency in the Portland Area".

The City Club of Portland was an organization of civic and business leaders created in the early 1920's 'to inform its members and the community in public matters and to 
arouse in them a realization of the obligations of citizenship" (Portland City Club, 1947, p. 157).

In addition, it is important to note that prior to this report, there were not existing codified statutes pertaining to juveniles. In fact, this particular bulletin made several recommendations that the future research into the development of an integrated children's code for the state of Oregon was long overdue.

The following provides a commonly accepted idea of what the term delinquency meant and how it was applied by law-makers during the 1940's and 50's:

\section{Legal Definition}

As of 1948, the Oregon Law, O.S.L.A. 96-603, states:

“...persons of either sex under the age of eighteen years who violate any city or village ordinance; or persistently refuse to obey family discipline; or are persistently refuse to obey family discipline; or are persistently truant from school; or associate with criminals or reputed criminals; or are growing up in idleness and crime or are found in any disorderly house, bawdy house, or house of ill fame; or are guilty of immoral conduct; or visit, patronize, or are found in any gaming house or in any place where any gaming device is or shall be operated, are hereby classed as delinquent children and shall be subject to the legal relations and provisions of the juvepile court law and other laws for the care and control of delinquents; provided however, that so far as possible all children under fourteen years of age accused of any of the above 
delinquencies until a court hearing takes place, shall not be regarded as neglected or dependent children, and shall not be arrested, although on petition they may be detained for their own and the community's welfare; and that none shall be classed as delinquent until their cases have been passed upon and an appropriate order entered therefore y a court of competent jurisdiction" (City Club of Portland, 1948-49.p. 157).

However, it should be noted that while this was a commonly accepted definition for the time, it still leaves a tremendous amount of discretion in the hands of awenforcement officials as to which children entered the juvenile justice system and who did not - discretion well associated with this pre-Gault era.

For example, prior to the 1967 Gault decision, the juvenile court was struggling to remove itself from the late 19th century role as "Parens Patriae"; which literally meant "Parent of the Country", or the role of the state as sovereign and guardian of persons under legal disability, such as juveniles or the insane (State of W. Va. V. Chas. Pfizer and Co., C.S. N.Y., 440 F.2d 1079, 1089), and in child custody determinations when acting on behalf of the state to protect the interests of the child. It is based on the principle that the state must care for those who cannot take care of themselves, such as minors who lack the proper care and custody from their parents (Black's, $1990, \mathrm{p}$. 1114.)

However, the Gault decision (387 U.S. 1, 87 S. Ct. 1428, 18 L. Ed. 2d 527.) involved a 1967 landmark Supreme Court case that guaranteed each juvenile 
defendant certain procedural safeguards such as: the right to confrontation; the privilege against self-incrimination; prior notice of the complaint and the right to counsel (Black's, 1990, p. 681).

Furthermore, the Gault decision not only catapulted the juvenile court out of the 19th century "Parens Patriae" role, but it also provided more balance between the juvenile court and the adult court systems of the 20th century.

\section{Delinquency in Portland}

In 1948, the City Club of Portland investigated juvenile delinquency in Poftland and reported the seriousness of the problem during the mid 1940's.

The following tables from their report present the overall trend in juvenile delinquency between 1937 and 1946, on both a national and local level. However, it is important to note that while statistics can be an extremely helpful and visually informative aid, they can also be manipulated. Therefore, they should not be taken as absolutes, because much if not all of statistical data is dependent on human calculation and thus subject to basic human error in the reporting and gathering of data, and in their storage and documentation. 
Table 12

National Trends - Total Cases

(from)

Juvenile Court Statistics, Children's Bureau, U.S. Department of Labor (56 courts serving areas with populations of 100,000 or more.)

$\begin{array}{lcc} & \text { TOTAL CASES } & \text { BOYS } \\ 1938 & 47,816 & 40,149 \\ 1939 & 52,800 & 44,981 \\ 1940 & 50,700 & 42,355 \\ 1941 & 55,064 & 45,074 \\ 1942 & 59,316 & 47,675 \\ 1943 & 78,692 & 63,972 \\ 1944 & 76,058 & 61,813 \\ 1945 & 79,748 & 66,047 \\ 1946 & \text { STATISTICS } & \text { NOT YET }\end{array}$

GIRLS

7,667

7,819

8,345

$\mathbf{9 , 5 9 0}$

11,641

14,720

14,245

।

13,701

AYÁLABLE

Source: Portland City Club, (1948). p. 159. 
Table 13

Local Trends -- Total Cases

(from)

Juvenile Court Statistics, Children's Bureau, U.S. Department of Labor. (Multnomah County).

YEAR

1937

1938

1939

1940

1941

1942

1943

1944

1945

1946
TOTAL CASES

672

832

889

830

957

1,208

2,719

3,205

2,801

2,919
BOYS
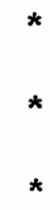

711

866

973

2,361

2,800

2,447

GIRLS

*

*

*

119

91

235

358

405

354

i

*Figures not available from Children's Bureau Reports.

NOTE: "The data are influenced by the working relationships between the court and other youth-serving and law-enforcement agencies in the community. For example, almost half of the increase of $125 \%$ in the number of delinquency cases disposed of by the Multnomah County (Oregon) court in 1943 compared 
with 1942, is due to a change in the handling of juveniles involved in traffic violations." CHILDREN'S BUREAU.

Source: Portland City Club, (1948). p. 159.

After reviewing the national and local trends in juvenile delinquency, it becomes evident that between 1938 and 1945, the nation experienced a 66\% growth oferall in arrests for juvenile delinquency, compared to an increase of $294 \%$ in Multnon ah County. It could be easily interpreted that juvenile delinquency in Portland inqeased more rapidly than the national average. However, a more accurate interpretation might be that individual states across the nation defined juvenile delinquency and delinquent acts differently, and thus arrested and incarcerated juveniles at different ages and for differentcrimes. Therefore, the overall growth on a local level mitht be expected to differ from that at the national level. Some states such as Oregon, and its Multnomah County, might have experienced a far greater increase in juvenile delinquency than the national increase due to the individual statutes governing juveniles and the application of those laws.

There are many ways in which law-enforcement practices impact arrest statiktics. However, one of the more prominent and perhaps visible involves police discretion. For example, "getting arrested is an interactional process, in that the police force, the 
police officer, the victim and the offender do make a difference in determining what is recorded as a crime" (Nettler, 1984, p. 46).

Juvenile delinquency is one such area in which that law-enforcement persomnel exercise a great deal of discretion if the crime warrants it, in hopes that they may steer young offenders away from the judicial system, or at the worst delay their ent-y into it.

In addition, coding variations seem to effect arrest statistics, in that political pressures and biases tend to be reflected in the overall policy and procedures of local police departments. A good example of this is discussed in Chapter 2, when mayor Earl Riley targeted low-income, racially isolated areas as the cause of criminal activity, overlooking the internal corruption of local politicians, business men and law- enforcement.

Finally, complaints by private citizens or actual victims tend to generate arrests, in that a large amount of police work seems to be reactive in nature rather than surveillance. Consequently, the rate of reported crime can fluctuate depending on the rate of community responsibility and concern over criminal activity. 
Table 14

Juvenile Delinquency Trends in Portland,

$1937-1946$

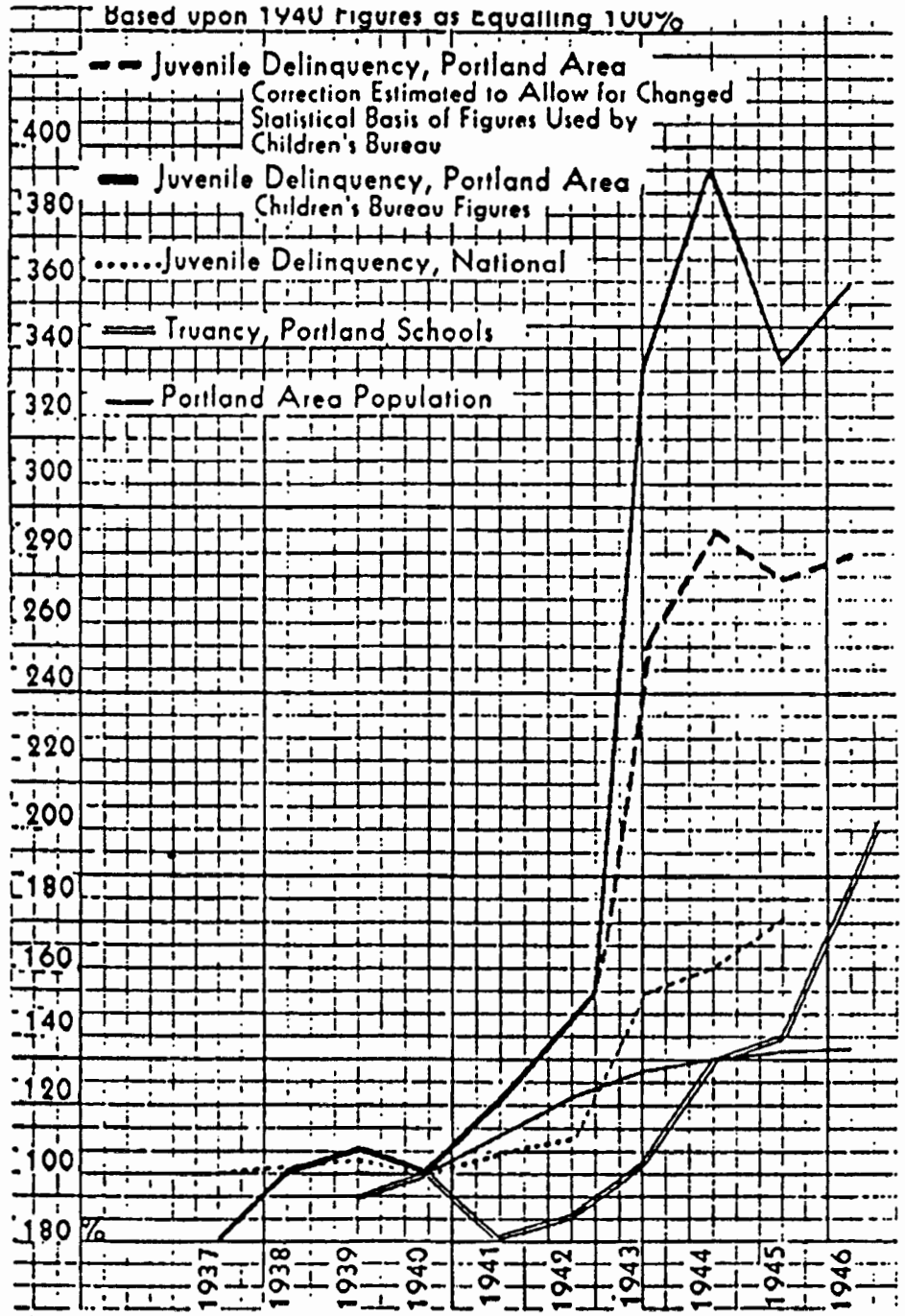

Source: Portland City Club, (1948). p. 160 
A brief summery of the annual report of the City Club, (1948), reads as follons:

'Despite the various interpretations of those statistical data, the overall view reasonably clear - i.e., 'Both local and national statistics show a rapid increase in the problem of juvenile delinquency during the second world war, 1939 to 1945 ; and that authorities in the field prophesied a continued increase in the post-war period of readjustment. This forecast seems justified by national statistics, and, to a lesser extent, by the experience of local officials." (City Club of Portland, 1948. p. 15\$).

Indeed, after reviewing the above statistical data and statements from scholan in the field, it becomes evident that juvenile delinquency was on the rise, with great potential for the post war years. For example, the survey below, compiled by L\&sie

M. Chase, of the Division of Investigation for Portland public schools, indicated definite increase in juvenile delinquency immediately following the second world war.

Table 15

Annual Report of Portland School Police In 1948, 4 Year Survey of all Reported Criphes.

$\begin{array}{ccccccc}\text { Year } & \text { Cases } & \text { Cases } & \text { Partially } & \% \text { of } & \text { Reported } & \text { Loss } \\ & \text { Reported } & \text { Cleared } & \text { Cleared } & \text { Cases } & \text { Loss } & \text { Recovery }\end{array}$

Cleared

$\begin{array}{lllllll}1944-1945 & 197 & 110 & 20 & 66.0 \% & \$ 6140.00 & \$ 1360.00 \\ 1945-1946 & 314 & 173 & 16 & 60.2 \% & \$ 5280.00 & \$ 1826.81 \\ 1946-1947 & 330 & 166 & 14 & 54.5 \% & \$ 4768.20 & \$ 2011.75 \\ 1947-1948 & 278 & 145 & 19 & 59.0 \% & \$ 4974.55 & \$ 2434.25\end{array}$

Source: Portland Public Schools, Annual Report, July 1, 1948. 
Furthermore, if we were to compare all previous tables with that of tables with that of table 16 and 17 , it becomes clear that today juvenile delinquency continues to increase, not only within Portland's schools, but within the state of Oregon.

Table 16

Portland: Violence-related crimes reported at Portland Schools. A Comparison of the 1992-1993 and 1993-1994.

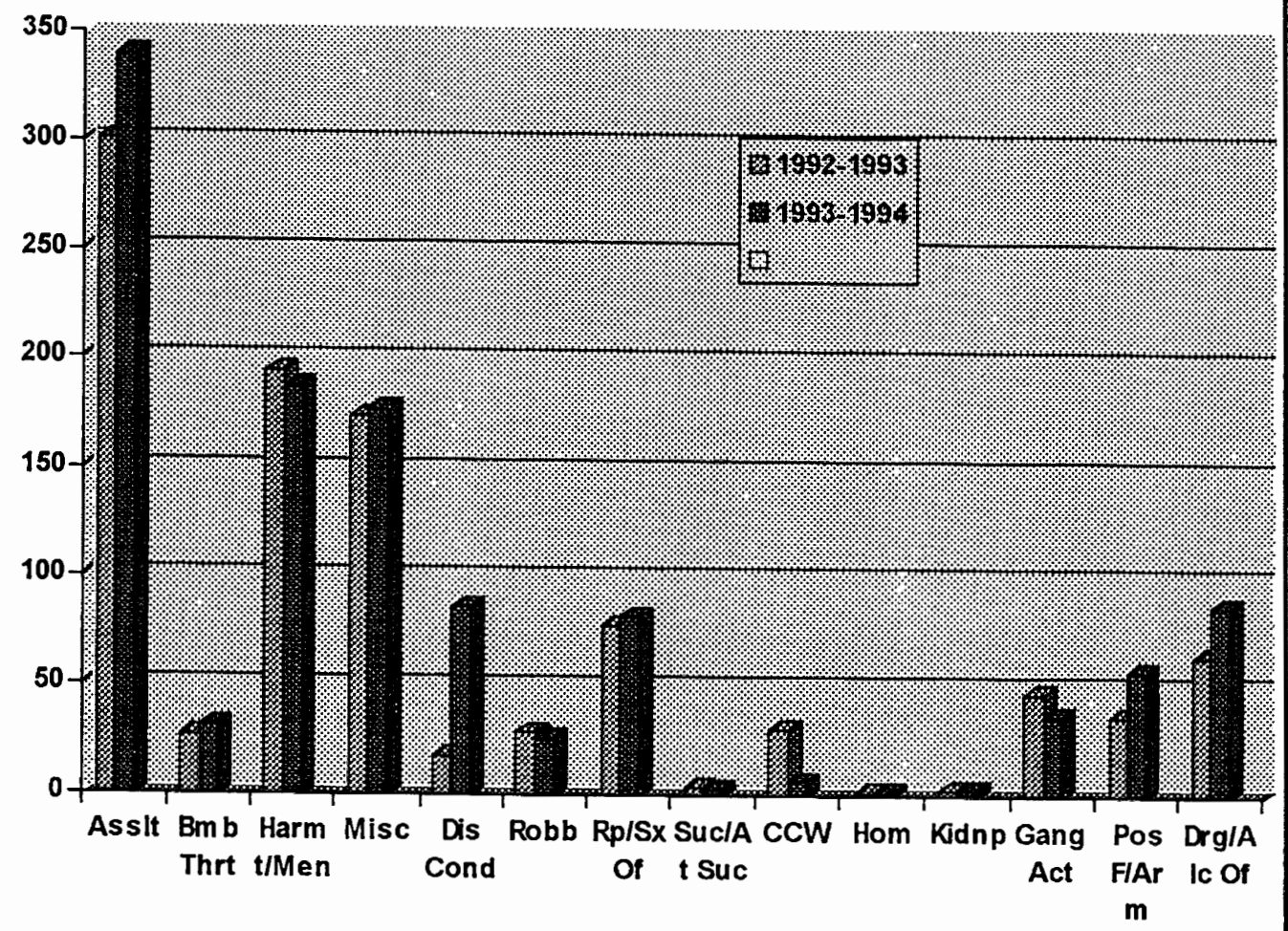

1992-1993 TOTAL $=1,011$

1993-1994 TOTAL $=1,124$

TOTAL INCREASE OF $11.2 \%$

Source: The Oregonian. "Making School Safe." October 16th, 1994. 
KEY: Table 16

Asslt: Assault

Suc/At Suc: Suicide and Attempted Suicide

Bmb Thrt: Bombs and Bomb Threats

CCW: Carrying a Concealed Weapo

Harmt/Men: Harassment and Menacing Hom: Homicide

Misc: Miscellaneous

Kidnp: Kidnapping

Dis Cond: Disorderly Conduct

Gang Act: Gang Activity

Robb: Robbery

Pos F/Arm: Possession of Firearm

Rp/Sx Of: Rape and Sex Offenses

Drg/Alc Of: Drug and Alcohol Offerses 
Table 17

State: Violence-related crimes reported at State Schools from elementary to collede. A Comparison of the Years 1992-1993 and 1993-1994.

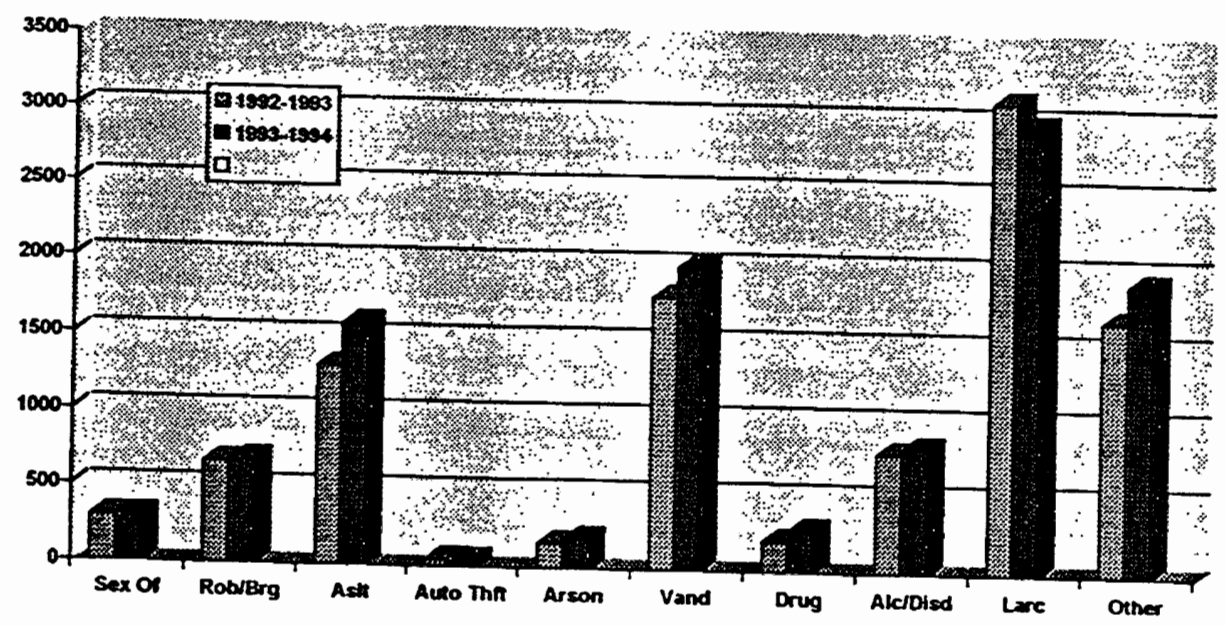

$$
\begin{aligned}
& 1992-1993 \text { TOTAL }=10,040 \\
& 1993-1994 \text { TOTAL }=10,759
\end{aligned}
$$

TOTAL INCREASE OF $7.2 \%$

Source: The Oregonian. "Making School Safe." October 16th, 1994. 
Key: Table 17

Sex Of: Sex Offenses

Rob/Brg: Robbery and Burglary

Aslt: Assault

Auto Thft: Auto Theft

Arson: Arson

Vand: Vandalism

Drug: Drugs

Alc/Disd: Alcohol, Disorderly Cpnduct

Larc: Larceny

Othr: Other

A brief summary of the 1948 Portland School Police annual report read as follows:

1. "The overall number of cases reported to the Division of Investigation have increased approximately 5\% over the 1946-1947 figures. Although the number of cases reported increased $5 \%$, the actual percentage of cases cleared increased $5.5 \%$ over the previous year. Property destruction and loss from theft wer. reported at $\$ 4,947$, recovery was $\$ 2,434$, thus showing a $48 \%$ total recovetry for theft and property damage.

2. Although the actual damage to school property was reduced, the number of break and enters into the school buildings showed a slight increase. The rise is in direct proportion to the fact that police records show a substantial rise for this ty case throughout the area.

3. Theft of school and personal property showed a slight increase. 
4. the ratio of boys and girls involved in delinquent acts were 191 boys 29 gils.

Percentage of juveniles with previous records increased $4 \%$ over the 1946-1947

figures. This again indicates an increase of a considerable amount of juveniles being investigated with previous records.

5. Age range frequency shows that for $1947-1948$, the predominate age was 12 and 14 years.

6. Finally, the report mentioned that a total of 27 cases were referred to the juvenile court for further treatment and investigation" (Portland Public Schools, Aanual Report: 1948, p. 1).

These data indicate that not only was juvenile delinquency on the rise in Portland, but that it had a significant impact on educational facilities - in particular those within the Portland metropolitan area. As a result, the local school districts organized and produced their own Special Investigators or School Police programs in an attezpt to document events and track juveniles not only through the school system, but through the juvenile justice system as well.

When the City Club of Portland published it's report on juvenile delinquency, in 1948 , they suggested a variety of contributing factors to juvenile crime and vio_ence. However, the overall belief or philosophy centered around three main concepts The first belief was that juvenile delinquency could be attributed to the lack of support and all-around care for the community; suggesting that crime on the whole 
could be significantly reduced if certain social and economic improvements vere made that expanded local institutional resources.

The second belief focused on education and individual enhancement, as a means of prevention and treatment of juvenile crime. The basic premise was that if the community as a whole took on the social responsibility of raising their youth, instead of it being placed on the teachers, then not only would it reduce juvenile crime, but it would establish a healthy environment for our youth.

The third belief was that in order to reduce juvenile crime, and provide effective treatment and prevention programs, community improvement would need to intertwined with individualized resources.

The City Club Report discussed the following local problems and needs: Standard of Living.

One of the first and probably more obvious problems was the standard of living, because the lack of adequate housing, economic security, medical care, opportupities and recreation may serve as a breeding ground for crime and violence. For example, gross inequalities such as these, while personally demeaning, tend to generate fnger and frustration on the part of individuals who may seek justification through violence. 


\section{Schools and Education.}

The school and its educators have an enormous social responsibility to both the community and to young adults, as they not only help shape the minds of our youth, but they also instill basic values and morals that allow children to become competent individuals in an increasingly competitive society; a responsibility that seems to be growing as parental guidance seems to be declining, as families struggle to keep up with the rapid economic growth, and single parent families are gradually becomhing the norm. Furthermore, it would be ignorant to think that our schools merely teach the three R's, as more often than not school personnel are the first to notice negattve behavior, and in many cases, the only place capable of caring for and initiating services, for those students with problems and/or basic needs, a responsibility that would surely shift to their peers if neglected by the schools.

Therefore, the future training of our teachers becomes a vital role in the shaping of our youth, as it requires a complete overhaul of teacher training institutes as solciety progresses, clearly an enormous expense, but weighed against the true cost of orime on our society it can not be brushed aside.

\section{Family Education and Social Services.}

One of the more courageous attempts by local officials to curb the gradual infcrease of juvenile delinquency was the introduction of a parent and teacher association that would work in conjunction with the growing field of social services. 
The thought behind such a union was to build a channel of communication between parents and teachers, in order to obtain a greater understanding of juvenile ad ivity both at home and in the schools. Furthermore, it was hoped that such a gathefing would produce a variety of collective decisions on how both the schools and could handle deviant juvenile behavior. One of the main solutions was to increase the awareness of and utilize the expanding agencies within the field of social servidees such as: the New Portland Child Guidance Clinic, for the treatment of disturbed chlldren; the Public School Visiting Teacher Service, that provided the school district vith psychiatric services, and a variety of mental health hygiene and medical schoo devoted to self-improvement of both the individual and family. Finally, an arrat of smaller support agencies such as church groups and community resources wo together to improve the overall standard of living, providing greater opportunities and improve education all around.

Juvenile Legislation/Courts and Detention Facilities.

At the time the City Club of Portland published its report on juvenile delinquepcy in 1948 , the laws pertaining to juveniles and child welfare had yet to be organized into an integrated children's code for the state of Oregon. For example, 'they cont tined many coutradictions, ambiguities and substantive lacks. They were progressive in many respects, but seriously in need of careful study, leading toward the development of an integrated Children's code for Oregon" (City Club of Portland, 1948, p. (78). 
The report further suggested that, while the juvenile court is responsible fo determining legal issues and providing treatment for a greater number of juve iiles, both in the area of delinquency and dependency, the court had also been expetiencing difficulties in finding and training qualified personnel. This was seen as a grouthng responsibility since Oregon lacked both the funding and qualified personnel to effectively operate supporting agencies. Consequently, the burden placed upont the courts to administer treatment to juveniles was overwhelming, and as a result fhany juveniles received both inadequate and punitive treatment. For example, up untiil 1967, it was not uncommon to sentence juveniles alongside adults, placing them in adult-orientated treatment centres and detention facilities.

For example, prior to 1946, Portland's only detention facilities were the Fraser Home, the Girl's Juvenile Home, the City and County Jails, Hillcrest and Woodburn, all of which were grossly overcrowded, under-staffed and poorly maintained facilities that seemed to encourage rather than deter delinquent behavior. In fact, it was hot long after the City Club published its findings, that the National Probation Assoclation produced a survey (The National Probation Survey of 1946) that required a colnplete overhaul of all detention facilities within the Portland Metropolitan area. (City thib of Portland, 1948. p. 179). 
The report concluded by stating:

"There are many contributing factors to the decline of our communities, the rise in youth crime and consequently the overall demise of the human spirit, morals and values, many of which we have discussed. However, it becomes evident that then a small city becomes an industrial giant almost over-night, experiencing an unpredictable growth in population, employment, transportation and community living, that it was only a matter of time before Portland began to experience thie side effects. For example, the post-war years witnessed a community riddled with confusion and discontent, as individuals lost interest in the concept of unity and togetherness, as they sought to maintain their homes, jobs and families. It was at this time that families started to experience the pressure and drift apart, as the responsibilities of raising our youth shifted into the hands of their own peers, nadio, movies, magazines and advertisements, as we began to glamorize the less important aspects of life and adopt a more irresponsible attitude of 'Boys will be Boys'.'

For example, 'the home, which once assumed almost the entire educational an industrial function in society, was rapidly loosing both functions; as the school one of societies afterthoughts, is half-expected to provide children both with the three $\mathbb{R}$ 's and with practice in living adjustments, which once were supplied by experienco n $n$ home and in work. The same society that passes legislation forbidding smoking and drinking by children, now permits or applauds greater expenditures in tobacco and 
liquor advertising than it provides for constructive direction of Youth" (City flub of Portland, 1948. p. 184).

Finally, the City Club of Portland made a variety of general recommendations that it believed would improve the overall problem of youth crime. Examples are:

1. A community council should be established, composed of representatives from the juvenile court, the schools, law-enforcement, local church groups and soc services. This council should meet on a regular basis to discuss general improvements in both the local community and the juvenile justice system on the whole.

2. Education on the whole needs to be expanded upon, perhaps as an intercollaborative effort between the children, the teachers, the parents and out tide social services. For example, teacher training institutions could produce qualified individuals, who are socially equipped to teach more than just the three R' as they introduce more innovative and more applicable tools to educate our y puth in a constantly changing society; while parents take on an equal responsibility outside school and in the home; and finally, in the field of social services, a a encies can join together in improving local neighborhoods through vocational guidance, and counseling clinics.

3. Local agencies should be provided with the necessary funds to implement community improvement programs, more vocational and recreational prograns 
for our youth and create greater involvement by local businesses in the community.

4. Laws pertaining to juveniles should be codified and institutions should undergo a complete overhaul if future expansion is to take place.

5. Finally, a youth authority should be created to investigate and make recommendations for the future needs of our juveniles within detention fadilities, along with coordinating state wide improvement programs for our youth Club of Portland, 1948. p.84-85).

In addition, it is important to note that many of these issues, fears and belieffs such as a breakdown in family values, loss of parental authority/guidance, and the dreation of a more toughened violent offender, seem to repeat themselves throughout time, creating what appears to be waves of "delinquency laments". An important lesrning tool is that if society can create effective crime control methods that coincide prith these waves of "delinquency laments", the increase in juvenile delinquency can be somewhat controlled.

Now that the factors contributing to delinquency in Portland have been dischssed, and some of their potential solutions have been highlighted, it is appropriate to shift to a focus on organizations that existed or were created to combat the rise in youth crime during the 1940's and early 1950's, particularly, the Portland Public School Police. 


\section{CHAPTER 4}

\section{PORTLAND PUBLIC SCHOOL POLICE}

\section{Formation.}

The Portland Public Police, or School Investigators as they were originally known, originated sometime during the late 1930's, when Edward Wolfe was appoint d d special investigator for Portland Public Schools; Wolfe was assigned specificalfy to investigate the consolidation and re-organization of debt brought upon the schlool district through theft of school property and vandalism. (Portland Public Schoh 1 Board minutes, June 28th, 1937, 11426-11643). (1)

This date of origination is contrary to the popular belief that the Portland Public School Police were formed in 1943-44 (The Oregonian, 1944, p. D1; the 1994 official handbook for Portland Public Schools; and the Portland Public School Investightor's Annual Report of 1947).

In 1937, Edward Wolfe was appointed special investigator and required to roport to both the Education and Legislative committee. In 1938, he produced his firs report to the superintendent of schools, highlighting the amount of damage incurred and materials stolen from the school district, a report that would be reproduced by his future successors. However, as the amount of theft and vandalism increased so did the need for extra hands. Leslie Chase, Special Investigator, 1944 to 1948, employed several part-time-special officers, regularly employed as custodians, to continue the 
investigations into the increase in criminal activity. Furthermore, it was at thi point in time that Chase simultaneously arranged for the organization of approximate 70 volunteers, all of whom were sworn in as auxiliary officers for the future protection of the schools district's property (Special Investigators Annual Report, 1946 to 947). And so began the expansion from a one-person operation into a fully funded, highly sophisticated and comprehensive school police department. (In 1994 it emplowed 22 full time sworn officers, under the immediate supervision of Chief Mac Lockett since 1965). Appendix I contains a chronology of important events in the early fordative years of the Portland Public School Police.

Comparison of the Functions of The Portland Public School Police; 1937 to 1950. and 1994 to 1995.

The Portland Public School Police originated in 1937, the year of the earlie documented appointment of a special investigator on record, and while its oridgnal mission statement has expanded from fighting school vandalism and theft, to investigating homicides, aggravated assault and acts sexual misconduct, so too have the departments goals.

From 1937 to 1950, the main objectives set down by both the Education an Legislative committees, were simply to evaluate and decrease the amount of mpotary loss incurred by the School District through acts of adolescent misconduct such as vandalism and theft. This is not as many see the department today, to providing o 
secure and productive learning environment both inside and outside the schocil through various departmental functions that require the full cooperation and understanding of educators, law-enforcement personnel, the community, fami $y$ and the students themselves.

Furthermore, it is important to note that objectives such as the ones mentianed

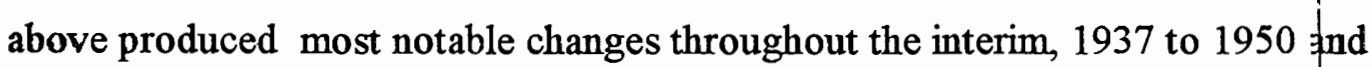
1994 to 1995 , in that as the school police program began to expand, so to did its objectives, and consequently the programs ability to provide greater community support, and student interaction.

It is also important to note that when the School District hired it's first investigator, they did so without consulting any parent or teacher association for special guidance or input, because many if not all of these support groups wers not formally in existence at this time. In addition, the School District felt that this was an internal decision; a decision the Education and Legislative committee felt more than qualified to make and, more importantly, well within their rights to do so withqut the prior consent of the community.

Right or wrong, the implementation of a special investigator into the public scchool system was an important event, both in the history of education and law enforcement.

In an interview, School Police Chief Mac Lockett (May 6th, 1994) stated that when the district first hired a special investigator, they did so without even rearzing the importance of their decision and the impact it would have in creating an actual 
school police department. In short, the school district had no real concept of what this position would yield in years to come.

School Police Chief Mac Lockett has served the School District for 29 years and while he is responsible for the supervision of various training programs, he oversees all routine operations of the School Police Department on a day to day basis. For example, the School Police Department currently has 20 sworn officers, three of whom are women, and all of whom undergo an 11 week training program at he state academy. Upon completion, each individual becomes certified and granted fü 1 police authority by the State Legislature. School police officers patrol 52 square mil school buildings, 9 of which are actual schools and are responsible for some 57,000 students. In addition, the department operates on a 24 hour a day basis, 365 days a year; quite a contrast from 1940, when H.J. Langoe was Chief; in that he was the only sworn individual responsible for 95 square miles, some 85 buildings, 7 of which were actual schools and approximately 307,500 students.

Today, an officer's responsibility stretches far beyond investigating vandalism, theft and creating a safe and secure learning environment for Portland's students; It addition, school police officers provide students with interactive communication seminars that not only increase the students' awareness of local ordinances and laws, but through the help of teachers, community volunteers and the students themselves, also provide conflict resolution and mediation skills that will enable students to resolve disputes both inside and outside the classroom on a daily and lifelong tasis. 
Furthermore, the goals of the School Police have expanded to improve the overall image of law enforcement. They now seek to enhance the student's knowledge of the legal system and participate in community service events that deal primarily with juvenile law, drug, alcohol and child abuse, (the latter has become one of the leading crimes reported to school police officers in Portland), legal updates and caree opportunities; All of which are performed on behalf of the school administration, and parent groups. (Portland Public School Handout, 1994).

Other differences over time include:

1. The department today is required by state law to file all police reports for of up to 7 years, along with presentation of an annual report to the school on juvenile crime. However, while the Special Investigators office did file an annual report, it was done so at first under the sole discretion of each appdinted employee, rather than by mandate. However, this too eventually became routine for the school district, and annual reports became a requirement at the end of each year.

2. Juveniles today appear to have much more contact with the courts and socha service agencies, (Refer to Tables 16 and 17), whereas many of the juveniles in the 1930's and 40's were dealt with primarily by the school district themsefyss, probably because there are simply more social service agencies and suppor groups available today than back in the 1930's and 40's. (See Chapter 2). In addition, school police officers today attempt to deal with all juvenile cases in a 
manner that is in the best interests of the child; a philosophy very similar to that of the pre-Gault era.

Throughout the duration of Chief Lockett's administration, he has adopted and shared many of his own philosophies with his staff, the school district, local community and students, concerning future policies and problems with the department.

Chief Lockett has stated that many districts have their own security departments within the schools, but rarely do they have their own police departments. Therefore, not only is Portland's school district very unique in that it has its own police department, but as previously mentioned, it is very well organized and deployed. In fact, Portland's School Police Department has played an active part in both educating and training other interested school districts across the nation in the policies and practices of law enforcement within the school.

In addition, it is the Department's intention to set their goals and mission statement around the interests and needs of school district and its students, and not around what is best for the city of Portland. However, this particular task has been made more difficult because many school children today believe that human life is not valkable, in that young offenders today appear to be resorting to more severe and more vidient means of committing a crime (See Tables 16 and 17). This lack of respect and accountability can be attributed to the restraints placed around punishing juveniles, 
along with the limited resources made available to parents, teachers and local police to both enforce the laws and prevent harmful juvenile activity.

Furthermore, the types of crimes juveniles are committing in the schools are more serious than those in the 1940's and 50's. For example, if we refer to chapter 1, page 2, we can see from an article published in the October 16th edition of The Oregonian, entitled "Making School Safe", that burglary, rape, robbery, assault, homicide and drug abuse are much more common in our school yards and consequently reqraire more attention and discipline than local police departments are able to provide City police cannot cover the volume of calls encountered within the schools. This alane has made the entire issue of school police extremely controversial, because if s.hool police were to become obsolete, local police departments would be forced to absorb the extra calls. This would result in extra work and "screening out" of those calls that are perceived to be less important, which in this particular instance would invcive a great deal of delinquent acts in and around the school yards (See Tables 16 and 17).

When questioned about what improvements the department would like to see, Chief Lockett responded:

An increase in sworn personnel and departmental equipment would be a welcome improvement, as not only would this enhance the overall efficiency of the department by curbing the increase in juvenile activity, but there would be more officers available to both support and perform educational seminars. 
Second, the department would encourage more support from the community, the family, school and court system to increase the resources available to school officers in their attempts to enforce the laws and educate students, and provide the monetary backing for enhanced teacher and officer training to introduce a more diverse educational curriculum into the classroom.

Therefore, if improvements in the resources such as the ones listed above here to take place, Chief Lockett believes that the overall attitude of students would mprove, so that once again there would be a greater appreciation and understanding for human life and family values.

Furthermore, when asked about the importance of school police and what the future held, Chief Lockett mentioned that school police were here to stay, and that their importance would only increase as time progressed. In fact, school polich have already become an essential part of Portland's educational programs because the local police can not provide the school district with either the quality of care, indivithual treatment, or safety and educational seminars that the school police provide. In short, politicians may ponder dissolving such a program, but the seriousness of juventle crime is increasing yearly, and the school district simply cannot afford to compromise the safety of the school, the children and the community. According to Chief Mac Lockett:

"Politicians come and go, but school police are here to stay". 
Finally, there seems to be at least two reasons why the Portland Public School Police were created in the late 1930's:

1. Due to a necessity, because of the increase in juvenile activity.

2. Due to the huge migration of people of color to Portland, and of their chitdren into the school system.

When questioned, Chief Lockett felt that the department originated because there was a demand for it, based on the belief that juvenile crime in Portland was gfadually increasing and the school district was absorbing a great amount of money in correcting the damage done by school vandals and arsonists. He did not feel that the department grew because of racism, but did acknowledge the fact that racism was a very important consideration during this time period. (It is important to note that these statements are simply his opinion and do not reflect the opinions of the fatire department). Chief Lockett also pointed out that the department's records were not preserved and little, if anything, is actually known about the department's formative years.

Despite the two previous reasons for creating school police, there are still nany civil libertarians who believe, that "stationing police in school buildings and empowering them to interrogate children would almost certainly lead to intruslons on their civil liberties and could be a long step toward a 'Police School" (Robinson, 1967, p. 278). For example, it has been expressed that having law-enforcement personnel within the school is an invasion of privacy not only within the schoo, but 
within the home. Indiscriminate interrogations of students would take place without the supervision or presence of school authorities or parents; and students woudd be more concerned with a network of informants than an actual education. Students would be under constant supervision from police and used by personnel to provide information regarding activities and opinions of parents, neighbors and other adults in the community; Finally, that untrained police officers acting as social workers would over-discipline and over-react to various student kinds of negative activity that would ultimately lead to continual surveillance, frequent questioning and harassment by officers;

However, it is important to note that while many of these beliefs/fears deserve serious consideration, many have yet to be substantiated. In fact, many School Resource Officer (SRO) programs across the country, (Atlanta, Tucson, Mich gan and Portland) have rejected many of these fears and concerns and produced annual reports that confirm positive feedback from both teachers and parents (Robinson, 1967, pp. 278-280).

Many school districts nation-wide believe the SRO program not only decreases juvenile crime and violence in the school, but that it also provides an all around improved attitude towards education, crime prevention, investigation and rehabilitation.

Finally, school police, although controversial, continue to play an important role in our community. However, while it seems that school police and/or special 
investigators have been given the direct responsibility to curb negative juvenile activity, there were many other supporting agencies during the 1940's and 50 's that contributed a vast amount of time and resources to fighting juvenile crime, many of which have matured over the years and play an active role in today's community.

For example, the following organizations originated during the 1940's and 50's as a direct result of the increase in juvenile crime and violence:

1. Citizens or Junior Police Clubs formed out of a direct response to the high rate of property destruction both inside and outside the school. They were well ofganized through collaboration with the Portland Police Department and School District, and managed to recruit students, teachers and parents to fight the increase in vandalism.

2. The Portland Police Department's juvenile division developed primarily because of an increase in juvenile crime within the school district. Officer Joe Coorley became the Division's Chief Officer, and reported directly to the Chief of Police. Officer Cooney's officers became an invaluable resource to the Portland Pablic School Police.

3. The Neighborhood Protection Volunteer Group was an organization created within every school district, and consisted of several neighborhood volunters that rotated shifts over a 24-hour period to report any irregular activities both in and around the schools. 
4. The Portland Police Auxiliary can be compared to reserve police officers foday, except their main purpose during the 1940's and 50's seemed to be to protect the school district's buildings, as breaking and entering of school buildings hald grown to unacceptable proportions. The organization of the Police Auxiliary begame instrumental in freeing sworn officers to regulate adult behavior within th city.

5. Finally, the School Administrative and Visiting Teacher Association allowed for internal discipline and referrals to take place when students committed mipor infractions. It was seen as an effective method of resolving certain juvenil infractions by removing police contact that would ultimately create a pern anent legal record of the incident.

For example, during the formative years, 1937 to 1953, juveniles who com hitted criminal acts were tried alongside adults, and it was not uncommon for young offenders to be housed in adult jails prior to their court appearances, and to bo sentenced in a similar fashion.

Today, young offenders are more fortunate, in that police officers exercise great deal of discretion before making an arrest. For example, the child's age, attitu fe, prior record and type of offense are just a few variables an officer considers prior to taking a child into custody.

However, if an arrest were to take place today in Multnomah County, Oregpn, the : juvenile would be housed in a juvenile detention facility and tried in a juvenile ourt, unless the offense warrants trial in adult criminal court. In addition, juveniles roceive 
the same due-process rights awarded to adults and receive a disposition exclusive to that of the juvenile court, in that the disposition is completely separate from that of an adult court.

Furthermore, between 1937 and 1953, young offenders were not as fortunate as today's youth, in that if a juvenile committed a crime on school property, local law enforcement were required to respond and carry out the investigation and arrest, with little concern for the future welfare of the child.

However, today School Resource Officers (SRO) have taken over this responsibility and are much more capable of addressing not only the concerns of local law-enforcement and school administrators, but also the needs of the delinquen1 child. 


\section{CHAPTER 5}

\section{Summary and Conclusions}

Chapter two focused on the economic, social and political history of Portl: nd d during the 1940's and 50's. It provided an overall perception of Portland anc its population during the war years, in an attempt to understand the enormous growth the City of Portland underwent in all aspects of everyday life, from employment and transportation, to overcrowding and housing.

Economically, Portland became an industrial giant overnight due in part to the Kaisers and their contract with the government to build ships for the war effoitt, that employed 94,000 workers in the three wartime Kaiser shipyards (See Chapter 2).

Socially, local Portlanders tolerated this dramatic population growth by compromising their negative and sometimes hostile feelings towards the wartime immigrants. However, once the war was over so too was their compromise, and racial hostility and segregation became more visible when the immigrants remained ith Portland.

Politically, there were strong movements by groups such as the Housing Aithority, real estate investors and City Council, to control and manipulate city housing projects, as Mayor Earl Riley seemed to be more concerned with local popularity and business ventures, than with the existence of illegal activities overseen by an underproductive, poorly organized and inadequately supervised Police Bureau. 
Chapter three focused on the extent of juvenile crime and violence not only within the City of Portland, but within the City's schools. It focused on the sudden growth in school populations, as the children of immigrant laborers began attending local schools, and it discussed the concern and reasoning behind the rise in juvenile srime within the school. For example, Multnomah County experienced a $294 \%$ increase in arrests for juvenile delinquency from 1938 to 1945, an increase many Portlanciers blamed on the population growth and immigrant students.

In addition, Chapter three discussed the burden now placed on the local schools to combat this rise in juvenile crime, the inability of the teachers to cope with the crime and the lack of preparation on the part of the School District to combat it.

Finally, the overall finding that resulted from this historical analysis, was that the local Police Bureau was unable to effectively handle the increase in juvenile crine, a belief strongly supported by the presentation of data in Chapter three, that suggested a genuine necessity for improved social and family services, teacher training programs, stronger juvenile legislation, improvements in juvenile detention facilities and school security, all of which was suggested with the intention to reduce juvenile crime and violence.

School safety and the safety of the students and faculty became an immediat? concern with the School District, as educators, law enforcement and the comminity at large, demanded to see a reduction in juvenile delinquency. Chapter four discusses 
one such agency the School District created to combat the rise in juvenile cripe - The Portland Public School Police.

However, Chapter four goes on to explain the implementation of various cther supporting agencies, that were created by both law enforcement and concern ad citizens. Agencies such as: The Citizens or Junior Police Clubs formed out of a direct response to the high rate of property destruction within the schools; The Poriland Police Department's juvenile division developed primarily because of an increase in juvenile crime within the school district; The Neighborhood Protection Volunteer Group developed a 24 hour neighborhood watch program; The Portland Police Auxiliary's main function during the 1940's and 1950's was to protect the sckool districts buildings; all of which formed out of a direct response to reduce juvenile delinquency.

- Chapter four discusses the agency's evolution from its founding member, to its current Chief of Staff. The chapter analyzes and compares the agency of yesterday to that of today, along with the many controversial issues surrounding its existence, such as the right to privacy, tracking and interrogation of students.

However, Chapter four reports on three important issues:

The first issue was discovered almost by accident through the course of the research, and stated that the School Police actually originated in 1937, as opposed to prior reports that the agency was formed during 1943-44; indeed this is a signficant discovery, as it is important to understand when, how and why a particular 
organization formed, in order to establish a solid foundation for its future, bazed upon a firm understanding of the past.

For example, as the legislature creates, eliminates and reforms policy, so co agencies such as the Portland Police Bureau, School District and School Polize, in their efforts to improve future endeavors; a task that is by no means an easy cone, and accomplished by reviewing prior legislation, laws and policies. However, it is important to note that without the availability of existing historical data many of these agencies would fall into the pitfall of progress, that could otherwise have been avoided. A significant point, as individuals on the whole are not as forgiving towards law enforcement agencies when human lives, destruction of property and dep-avation of one's liberty are at stake. Therefore, it becomes apparent why the knowledge of one's past, becomes pertinent to the success of ones future.

Second, the purpose of this thesis was to research and analyze two questions:

1. Why did the Portland Board of Education create their own police?

There were two existing arguments as to why the School Police originated during 1937. The over-whelming belief, supported by research and a personal interview with the current Chief, suggests that the School Police formed primarily out of necessity to curb the overall rise in juvenile crime. This problem created a significant monetary loss for the school district and a demand from the community to provide greater resources in order to combat delinquency. Those resources came in the form $\mathrm{cf}$ a special investigator. 
In addition, Chief Lockett did state that although racism was rife throughout Portland during this time period, he felt his department was created out of ne:ssity as opposed to bigotry.

However, it is important to note that, even though most of the historical literature may support this view, there exists clear racist and classist factors that may have inspired the hiring of a Special Investigator, as the beginning of a special school police. The intimidation and hostility that Portlanders felt towards minority migrant workers during the industrialization period cannot be ignored.

2. What were the functions of the Portland Public School Police?

Since its formation in 1937, the Portland Public School Police have expanded its original mission statement from fighting school vandalism, theft and arson to also include preventing homicides, aggravated assault and acts of sexual miscondust in general.

Furthermore, as the Department's original mission statement has expanded, so too has its goals. For example, the department's original objectives, throughout its formative years, were simply to evaluate and decrease the amount of monetary loss incurred by the school district due to acts of adolescent misconduct;

Today, the department is much more complex; it aims to provide a safe and healthy learning environment both inside and outside the school.

In addition to the primary goals, the department now carries out various jot-related activities that were thought to be unimportant during its formative years, such as 
providing students with interactive communication seminars, conflict resolution and mediation skills and participating in community service events. All of these are seen as facilitating the basic functions of crime prevention, investigation and rehabilitition.

Finally, the current Department duplicates many of the activities the special investigator's office carried out; the only difference now is that the administration, personnel, communications, transportation, student population, number of schools, resources, juvenile legislation and community expectation have expanded. The department now accepts a greater responsibility to the school district, the corrmunity and to the students themselves.

I approached this thesis with great expectations about discovering why the Portland Public School Police were created. I hoped that I would unearth some controversial issue that based their origins on more than political expediency. However, after extensive research I could not ignore the fact that juvenile crime was on the rise and that the local community and School District became tired of playing the victim, and demanded a solution to combat the rise in juvenile delinquency: This solution came in the form of the Portland Public School Police, and after decales of active duty, this department has become a model for school districts around the nation. For example, School Police Chief Mac Lockett has stated that he receives several requests each year, from around the country, asking for guidance in forming new departments. 
However, it cannot be ignored that the concept of school police was a phenomenon that had yet ot be evaluated, yet law enforcement, the school district and the community in general viewed it as an answer to controlling the rise in youth is unknown at this time why the option to introduce police into the schools outweighed any other concept, except all those concerned wanted to see a reduction in juvenile crime, and powerful enough to face any of their opposition; which at this particular point in time were politically non-existent, in that the only concern s seemed to come form the various ethnic groups, who feared that the introduction of dice in the schools, was merely an effort by the white majority to provide protection to the majority of white youth.

Clearly, the idea of police in the schools has brought about many controversial issues. However, there are approximately 200 departments in existence today. number that continues to grow primarily out of demand for control of an overall increase in violent juvenile crime.

For example, Richard Riley reported in the January 1994, edition of USA Tidday, (p. 37). that:

- In April, 1993, three teen-agers armed with a baseball bat, billy club and thack knife burst into a high school social studies classroom in Dartmouth, Mass., and fatally stabbed a 16 year old freshman in front ot the class.

- In March, 1993, a high school student in Harlem, Ga., opened fire in a school hallway, killing one teenager and injuring another. 
- In November, 1992, the principal of a grade school in Brooklyn, NY., was caught in a cross fire on the street while he searched for a missing pupil and was litled.

"These incidents occurred in urban, suburban and rural areas. They happen rich school districts and poor ones" and while many tabloid articles seem to exaggerate incidents purely for shock value, these incidents have occurred, and represent the violent trends in today's youth. (Riley, R. USA Today ${ }_{2}$ January 1994 , p. 36-38.)

School violence is on the rise across the nation, and denying its existence only prolongs the problem. For example, 'violence in schools or among school aged youth not only destroys the nation's most precious natural resource - its children - buttit also creates an environment where youngsters can not learn, teachers cannot teach and parents are reluctant to send their offspring to class.

We must start by creating an environment, free of drugs and violence - both a challenge and a necessity. Raising the graduation rate, improving academic achievement, and ensuring the ability of American youngsters to compete in a vorld economy are critical to the nation's future. However, achieving these goals wi. be nearly impossible if schools and neighborhoods remain unsafe.' (Riley, R. USA Today, January 1994, p. 36-38.)

We, as a society, can no longer allow the media to influence our children, we have to take on the responsibility in the homes and allow the schools to create the find 
tuning; we can no-longer expect our educational institution to absorb the burden of our social decay.

Indeed, school police are controversial, but they are providing a service (lawenforcement, community relations, safety and education) we as a community and as parents, have neglected to provide. Furthermore, it is my belief that school p.jlice are here to stay, until we as a society can take more of a responsibility in raising our youth.

If future research were to continue in this field, I would suggest analyzing the concept of a merger between school police and local law enforcement, as this seems to be a very controversial subject within the school district today; alongwith an even deeper analysis of the role of the school police today. 


\section{APPENDIX I \\ CHRONOLOGY OF IMPORTANT EVENTS IN THE \\ FORMATIVE YEARS OF THE PORTLAND \\ PUBLIC SCHOOL POLICE}

The following chronological date-calendar outlines the first 30 years of the Portland Public School Police, from 1934 to 1964. Much of it contradicts recent literature published by Portland Public Schools, which states that the School Police originated in 1946 as opposed to my findings for 1937. However, after reviewing over 30 years of School board minutes, it was discovered that the earliest do umented notations in reference to special investigative agents within the school district was unearthed in the School board minutes for December of 1934, when the former position of Special Agent was officially withdrawn from Portland Public Schools. It is important to note that no earlier documentation regarding special investigators could be found.

Now, it is important to note that this statement alone does not imply the ac:ual formation of the Portland Public School Police. Rather it indicates that the idea of a school police department was beginning to take shape through what was knornu as a Special Investigator; and it was not until 1937 when Edward Wolfe became the School District's very first Special Investigator, that the evolution of the Portland Public School Police really started. 
DEC 12, 1934 THE FORMER POSITION OF SPECIAL AGENT WAS

OFFICIALLY WITHDRAWN FROM PORTLAND PUBLI SCHOOLS. PPSBM: 9959

JUN 28, 1937 EDWARD WOLFE WAS APPOINTED SPECIAL INVESTIGATOR PORTLAND PUBLIC SCHOOLS, AND WAS REQUESTED TO REPORT TO BOTH THE EDUCATION AND LEGISLATIVE COMMITTEE CONCERNING CONSOLIDATION AND REEORGANIZATION OF DEBTS. INITIALLY, ALL MATTEKS INVESTIGATED WERE TO BE REVEALED FIRST TO THE SUPERINTENDENT OF SCHOOLS. HIS MONTHLY SAI ARY WOULD AMOUNT TO \$125. PPSBM:11426/11646

JAN 10, 1938 EDWARD WOLFE, SPECIAL INVESTIGATOR FOR POR RLAND. PUBLIC SCHOOLS, PRODUCED THE DISTRICTS FIRS ANNUAL REPORT. THE REPORT CONTAINED ESTIMATES FOR THE AMOUNT OF DAMAGE INCURRED AND MATERIALS STOLEN FROM THE SCHOOL DISTRICT. PPSBM:11768

JUN 8, 1939 EDWARD WOLFE RESIGNED AS SPECIAL INVESTIGAATOR FOR PORTLANDPUBLIC SCHOOL DISTRICT \#1. PPSBN: 12788 
JUN 22, 1939 H.J. LANGOE REPLACED EDWARD WOLFE AS SPECIAC INVESTIGATOR FOR AN ANNUAL SALARY OF $\$ 1,500$. PPSBM: 12831

FEB 8, 1940 H.J. LANGOE FILED HIS FIRST REPORT WITH THE SCHOOL DISTRICT ON BEHALF OF SPECIAL INVESTIGATIONS PPSBM:13264

OCT 11, 1944 LESLIE CHASE WAS ELECTED TO REPLACE H.J. LAN \&OE AS SPECIAL INVESTIGATOR FOR AN ANNUAL SALARY $\$ 2,700$, PLUS THE COST OF LIVING. PPSBM: 15824

SEP 12, 1945 SPECIAL INVESTIGATIONS, PRODUCED IT'S ANNUAI REPORT FOR ACTIVITY BETWEEN OCT 20TH, 1944 ANID JUNE 31ST, 1945. PPSBM:16165

MAR 13,1946THE EDUCATION COMMTTEE OFFICIALLY APPOIN EED LESLIE CHASE AS SPECIAL INVESTIGATOR REPLACD G H.J. LANGOE. PPSBM: 16400

SEP 11,1946 LESLIE CHASE FILED THE SPECIAL INVESTIGATORS ANNUAL REPORT. PPSBM:16623

AUG 28,1947 LESLIE CHASE FILED THE SPECIAL INVESTIGATORS ANNUAL REPORT.PPSBM:17116 
JUL 22, 1948 THE COMMITTEE ON EDUCATION APPOINTED LEON ARD SCHMURR TO REPLACE LESLIE CHASE AS SPECIAL INVESTIGATOR, AS THE ANNUAL REPORT OF SPEC MAL INVESTIGATIONS WAS FILED. PPSBM:17621/17640 JUN 12, 1951 LEONARD SCHMURR WAS RE-APPOINTED AS SPECIAL INVESTIGATOR BY THE COMMITTEE ON EDUCATION, NOW KNOWN AS THE BOARD OF EDUCATION. PPSBM:377 JUN 24, 1952 LEONARD SCHMURR WAS RE-APPOINTED ONCE MORE. JUN 10, 1954 JAMES SERGEANT WAS APPROVED AS A SPECIAL INVESTIGATOR ALONGSIDE LEONARD SCHMURR. PPSBM:3392

JUL 11, 1955 BEATRICE REIMER WAS APPOINTED SECRETARY OH SPECIAL INVESTIGATIONS. PPSBM:4324

JUN 25, 1956 BOTH LEONARD SCHMURR'S AND JAMES SERGEAN EMPLOYMENT WAS CONTINUED BY THE BOARD OF EDUCATION. PPSBM:5102/6218 NOV 11,1957 EVALYN. KNUTSEN REPLACED BEATRICE REIMER A SECRETARY TO SPECIAL INVESTIGATIONS. PPSBM: $\$ 386$ 
JAN 13, 1958 FUNDS WERE APPROVED BY THE BOARD OF EDUCATIION FOR THE FUTURE EMPLOYMENT OF VARIOUS GUARDS TO REPRESENT THE OFFICE OF SPECIAL INVESTIGATIONS. PPSBM:6513

JUL 14, 1958 FURTHER/ADDITIONAL FUNDS WERE ALLOCATED FDR THE FUTURE EMPLOYMENT OF VARIOUS GUARD TO REPRESENT THE OFFICE OF SPECIAL INVESTIGATIONS. PPSBM:7016

AUG 10,1959 AGAIN, ADDITIONAL FUNDS WERE ALLOCATED FOR FUTURE DEPARTMENTAL EMPLOYEES. PPSBM:85

FEB 8, 1960 ONCE MORE ADDITIONAL FUNDS WERE ALLOCATE $\$$ FOR ADDITIONAL EMPLOYEES. PPSBM:544

JUN 10, 1961 FUNDS WERE APPROVED BY THE BOARD OF EDUCA fIION FOR THE PURCHASE OF 2 WAY RADIOS FOR THE ADVANCEMENT OF THE OFFICE OF SPECIAL INVESTIGATIONS. PPSBM: 1964

JUL 10, 1961 THE BOARD OF EDUCATION APPROVED SALARIES F RR THE ENTIRE OFFICE OF SPECIAL INVESTIGATIONS. PPSBMT:1933 
NOV 12,1962 THE BOARD OF EDUCATION APPROVED MISCELLA WEOUS SALARIES FOR THE CONTINUED EMPLOYMENT OF GUARDS TO THE OFFICE OF SPECIAL INVESTIGATIфNS. PPSBM:4229

MAY 11,1964 BOARD OF EDUCATION APPROVED THE FUTURE EMPLOYMENT OF ROY EDWARDS TO THE OFFICE OF SPECIAL INVESTIGATIONS. PPSBM:5642

JUL 131,1964 BOARD OF EDUCATION APPROVED MISCELLANEOU SALARIES FOR THE SPECIAL INVESTIGATIONS DEPARTMENT. PPSBM:5857

- PPSBM = IS AN ABBREVIATION FOR PORTLAND PUBLIC SCHODL BOARD MINUTES.

- It is important to note, that the above chronological date-calendar lists of hy those events that the Portland Public School Board considered pertinent at the time to document in the minutes. In short, many minor events may have been omittled in the evolution of the Portland Public School Police, however, the above calendar does present the readers with some idea of it's formative years.

- The information contained in this dateline, was obtained from the personal notations of the late Ada Praseau, an administrative employee of the School District that had taken a personal interest in the Special Investigators Office. 


\section{BIBLIOGRAPHY}

Abbott, Carl. (1983). Portland: Planning, Politics and Growth in a Twentieth Century

City. Lincoln and London: University of Nebraska Press.

Black, Henry, C, (1990). Black's Law Dictionary. St. Paul, Minn: West Pub isshing Co.

Boothe, James E., L. H. Bradley, T. M. Flick, K. E. Keough, and S. P. Kirk.

“America's Schools Confront Violence.” USA Today Jan. 1994: 33-35. Bureau of Census. (1952). Census Population, 1950: Characteristics of the

Population. Vol. II, Part 37. Oregon.

Conley, John A. "Historical Perspective And Criminal Justice". Journal of Criminal Justice Education, Vol. 4 No. 2, Fall 1993: pp. 349-360.

DeMarco, Gordan. (1990). A Short History of Portland. San Francisco: Lexikds East, Allen. Field Report, July 1946: A Survey of Juvenile Delinquency Cont fol in Counties of Oregon Outside of Multnomah County. Portland, OR: Govefnors Juvenile Delinquency.

Eisenman, Russel. "Society Confronts The Hard-Core Youthful Offender." UsA

Today Jan. 1994: 27-28.

Fox, James A., and G Pierce. "American Killers Are Getting Younger." USA Ioday Jan. 1994: 24-26. 
Gibbons, Don., and M. Krohn. (1991). Delinquent Behavior. New Jersey: Prqntice Hall.

Goldstein, Arnold P., S J Apter, and B Harootunian. (1984). School Violence Prentice Hall: Englewood Cliffs, N.J.

League of Women's Voters of Portland. (1964). “A Survey: Status of Equal Opportunities in Portland". Portland, Oregon.

Lendaris, G.G. "On Systemness and the Problem Solver: Tutorial Comments." July/August 1986. Vol. SMC-16, No. 4. 604-610.

Little, William A., and James Weiss, eds. (1978). Blacks.In Oregon: A Statistical and Historical Report. Portland State University: Black Studies Center and Oenter for Population Research and Census.

Lockett, Mac. Chief, Portland Public School Police Department, School Dist 1. Interview. May 16th, 1994.

* MacColl, E. Kimbark. (1979). The Growth of a City: Power and Politics in Pfrtland, Oregon 1915 to 1950. Portland: Georgian Press.

Mahoney, Ann. (1987). Juvenile Justice in Context. Boston: Northeastern Unfversity Press.

McCusker, Michael. "Vanport: The Town Nobody Wanted," Metropolis Dechnober 1973.

Meehan, Brian T. 'When Kaiser Launched a Thousand Ships, The Oregonian (December 3, 1992), sec: A1. 
Milander, Henry. "Communication Patterns: Police and Schools." Police Chilf 42 (June 1975): 59-60.

Morrison, June. "The Controversial Police-School Liaison Programs." Police 13 (Nov/Dec. 1968): 60-64.

Nettler, Gwynn. (1984). Explaining Crime. New York: McGraw Hill Book oo

Northup, Dun. ed. (1940). Understanding Delinquency. Oregon: The Departhent of Domestic Relations.

Polk, R.L. (1943-1944). Portland City Directory. Portland, OR: Polk and cothpany, Vol. LXX: 2615-2616

Portland Bureau of Planning. (1993) The History of Portland's African Ametican Community, 1805 to the Present. Portland, Oregon.

Portland City Club Bulletin. Education: Racial Isolation and Disadvantaged. $49-50$ (June/May 1968-1970): 16-26.

Portland City Club Bulletin. Juvenile Delinquency in the Portland Area. 28 (March 1948): 156-189.

Portland City Planning Commission. (1957). Staff Report: Portland's Economic Prospects: A Study of the Portland Standard Metropolitan Area with Estimates of 1975 Employment by Industry. Portland, Oregon.

Portland Public Schools. Annual Reports: School District No. 1: Multnomah OR: 1943 to 1944 and 1950 to 1951. 
Portland Public Schools. Annual Report: Division of Special Investigation, School

District No. 1. Portland, OR: 1940 to 1948.

Portland Public Schools. School District No. 1: Board Minutes. Multnomah County, OR: 1930 to 1954.

"Professional Notes and Comments." (1994). Praseau, Ada. Special Investightors

Office, Portland PublicSchool District No. 1. Portland, OR: 1994.

Quarles, Chester L. (1989). School Violence: A Survival guide for Schools staff.

Washington D.C. NEA Professional Library, National Education Assoctation.

'Real Estate Appraisals, A Transcription of Lectures and Discussions Given at the

Real Estate Classes of General Education Division, Oregon State Systeme of

Higher Education, in Cooperation with the Portland Realty Board" (Pottland,

1939) 144, Moores Papers, in possession of Mrs. Wayne Rogers, Portlahd.

* Riley, Richard W. "How to Save Our Children: Curbing youth Violence." U\$A

Today Jan. 1994: 36-38.

Robinson, Donald. 'Police In The Schools." Phi Delta Kappan 48 (Feb. 196f): 278280.

Scheffer, Martin W. (1987). Policing from the Schoolhouse: Police-School Liaison

and Resource Officer Programs. Illonois: Thomas Publishing.

"School Violence Erupts." The Oregonian 15th Nov. 1993, sec C: 1.

* Shepard, George H., and J James. 'Police, Do They Belong in the Schools?' American Education 3 (Sept. 1967): 2-4. 
Stevens, Ronald D. “Gangs, Guns, and School Violence.” USA Today Jan.

32.

Suratt, James and W Katzenmeyer. "Police Services for Public Schools". Auterican Education 3 (Sept. 1967): 2-4.

The Oregonian. "Data Show Youths Commit Growing Share of Killings." December 31st, 1993.

The Oregonian, "Chief of Police Draws Full Responsibility Vollmer Stresses in

Proposing Reforms." January 15th, 1948.

X The Oregonian. "Making School Safe: Violence Related Crimes Rise In Schbols." October 16th, 1994.

The Oregonian. "School Violence Erupts." November 15th, 1993.

The Oregonian. "The Ship Builders". February 26th, 1995.

Tracy, Charles. (1976). Evolution of the Police Function in Portland, Oregon.

Doctoral Dissertation. University of California, Berkeley.

U.S. Bureau of Census. (1991). Statistical Abstracts of the United States. Washington: U.S. Government Printing Office.

U.S. Department of Justice. Crime in the United States: 1982 Annual Repont. Washington: U.S. Government Printing Office.

U.S. Department of Justice. Juvenile Court Statistics: 1992 Annual Report. Pennsylvania: Office of Juvenile Justice and Delinquency Prevention. 
U.S. Department of Justice. Juvenile Justice: 1991 Annual Report. Arlington. of Juvenile Justice and Delinquency Prevention.

U.S. Department of Justice. (1991). School Crime: A National Crime Victimization Survey Report. Washington: U.S. Government Printing Office.

U.S. Department of Justice. The President's Commission on Law Enforcemeft and Administration of Justice. Task Force Report, 1967: Juvenile Delinquenqvy and Youth Crime: Juvenile Justice and Consultants' Papers. Washington: U.\$. Government Printing Office.

U.S. Department of Justice. National Institute of Justice Update, Jan. 1995: Weapon-

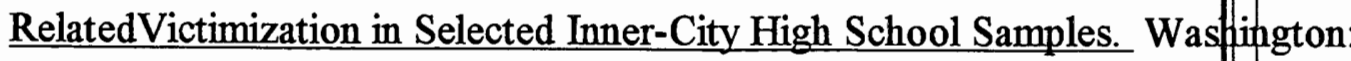
U.S. Government Printing Office.

Vollmer, August., and F. Addison. 'Police Bureau Survey, City of Portland, Report. University Of Oregon, Bureau of Municipal Research and Service. Eugence, Oregon: 1947.

Wesley, Charles H. (1984). The History of the National Association of Colofled

Women's Club: A Legacy of Service. Washington D.C.: NACWC.

Williams, William A. (1966). The Contours of American History. Chicago: Quadrangle Books, Inc.

Wilson, John. "Police Officers in the Classroom." Social Education 48 (April 1984): 266-284. 